\title{
Technical note: Emission factors, chemical composition, and morphology of particles emitted from Euro 5 diesel and gasoline light-duty vehicles during transient cycles
}

\author{
Evangelia Kostenidou ${ }^{1}$, Alvaro Martinez-Valiente ${ }^{2}$, Badr R'Mili ${ }^{1}$, Baptiste Marques ${ }^{1}$, Brice Temime-Roussel ${ }^{1}$, \\ Amandine Durand ${ }^{1}$, Michel André ${ }^{3}$, Yao Liu ${ }^{3}$, Cédric Louis ${ }^{3}$, Boris Vansevenant ${ }^{3}$, Daniel Ferry ${ }^{4}$, Carine Laffon ${ }^{4}$, \\ Philippe Parent ${ }^{4}$, and Barbara D'Anna ${ }^{1}$ \\ ${ }^{1}$ Aix-Marseille Univ, CNRS, LCE, Marseille, France \\ ${ }^{2}$ IRCELYON, UMR 5256 CNRS, Université de Lyon, Villeurbanne, France \\ ${ }_{3}^{3}$ AME-EASE, Univ Gustave Eiffel, IFSTTAR, Univ Lyon, Lyon, France \\ ${ }^{4}$ Aix-Marseille Université, CNRS, CINaM, Marseille, France
}

Correspondence: Evangelia Kostenidou (vkostenidou@gmail.com) and Barbara D’Anna (barbara.danna@univ-amu.fr)

Received: 11 August 2020 - Discussion started: 4 September 2020

Revised: 31 January 2021 - Accepted: 1 February 2021 - Published: 26 March 2021

\begin{abstract}
Changes in engine technologies and aftertreatment devices can profoundly alter the chemical composition of the emitted pollutants. To investigate these effects, we characterized the emitted particles' chemical composition of three diesel and four gasoline Euro 5 light-duty vehicles tested at a chassis dynamometer facility. The dominant emitted species was black carbon (BC) with emission factors (EFs) varying from 0.2 to $7.1 \mathrm{mg} \mathrm{km}^{-1}$ for direct-injection gasoline (GDI) vehicles, from 0.02 to $0.14 \mathrm{mg} \mathrm{km}^{-1}$ for port fuel injection (PFI) vehicles, and 0.003 to $0.9 \mathrm{mg} \mathrm{km}^{-1}$ for diesel vehicles. The organic matter (OM) EFs varied from 5 to $103 \mu \mathrm{g} \mathrm{km}^{-1}$ for GDI gasoline vehicles, from 1 to $8 \mu \mathrm{g} \mathrm{km}^{-1}$ for PFI vehicles, and between 0.15 and $65 \mu \mathrm{gm}^{-1}$ for the diesel vehicles. The first minutes of coldstart cycles contributed the largest PM fraction including BC, $\mathrm{OM}$, and polycyclic aromatic hydrocarbons (PAHs).

Using a high-resolution time-of-flight mass spectrometer (HR-ToF-AMS), we identified more than 40 PAHs in both diesel and gasoline exhaust particles including methylated, nitro, oxygenated, and amino PAHs. Particle-bound PAHs were 4 times higher for GDI than for PFI vehicles. For two of the three diesel vehicles the PAH emissions were below the detection limit, but for one, which presented an after-treatment device failure, the average PAHs EF was $2.04 \mu \mathrm{g} \mathrm{km}^{-1}$, similar to the GDI vehicle's values.
\end{abstract}

During the passive regeneration of the catalysed diesel particulate filter (CDPF) vehicle, we measured particles of diameter around $15 \mathrm{~nm}$ mainly composed of ammonium bisulfate. Transmission electron microscopy (TEM) images revealed the presence of ubiquitous metal inclusions in soot particles emitted by the diesel vehicle equipped with a fuelborne-catalyst diesel particulate filter (FBC-DPF). X-ray photoelectron spectroscopy (XPS) analysis of the particles emitted by the PFI vehicle showed the presence of metallic elements and a disordered soot surface with defects that could have consequences on both chemical reactivity and particle toxicity.

Our findings show that different after-treatment technologies have an important effect on the emitted particles' levels and their chemical composition. In addition, this work highlights the importance of particle filter devices' condition and performance.

\section{Introduction}

On-road diesel and gasoline vehicles are an important source of urban air pollution, releasing fine particulate matter $\left(\mathrm{PM}_{1}\right)$ and gaseous pollutants into the atmosphere (Dallmann and Harley, 2010; Borbon et al., 2013; Platt et al., 2014; Argyropoulos et al., 2016; Hoffman et al., 2016; Gentner et al., 
2017). Light-duty vehicle pollutants have been associated with adverse effects on human health, inducing cardiovascular, respiratory, and cognitive diseases (Hime et al., 2018, and references therein). Modern vehicles also produce $\mathrm{CO}_{2}$ and BC, which impact the climate (Lelieveld et al., 2019). In recent years vehicle emissions have received a great deal of attention. Different approaches have been used for their quantification, including tunnel studies (Grieshop et al., 2006; Lawrence et al., 2013; Dallmann et al., 2014; Smit et al., 2017), remote sensing or roadside measurements (Jimenez et al., 2000; Peitzmeier et al., 2017; Ropkins et al., 2017), on-road (chase) measurements (Canagaratna et al., 2004; Morawska et al., 2007; Hudda et al., 2013; Karjalainen et al., 2014), on-board measurements (Huo et al., 2012; Chikhi et al., 2014), and chassis dynamometer facilities (e.g., Andersson et al., 2014; Collier et al., 2015; Karjalainen et al., 2014; Saliba et al., 2017; Jaworski et al., 2018; R'Mili et al., 2018).

Improved information about the chemical composition of PM is essential to understand source contributions, implement mitigation measures, and assess health protection programmes. PM vehicle emissions are mainly composed of $\mathrm{BC}$ and organic aerosol (OA) due to the incomplete combustion of fuel and release of lubricating oil droplets. Less abundant components of vehicle exhausts include sulfate and metal traces (Maricq, 2007; Cheung et al., 2010). Sulfur and trace elements such as $\mathrm{Fe}, \mathrm{Zn}, \mathrm{P}, \mathrm{Mg}$, and $\mathrm{Ca}$ are commonly used as additives in lubricant oils (Maricq, 2007; Rönkkö et al., 2014; Liati et al., 2018). The above elements have been correlated to the oxidative potential, indicating the toxic nature of these emissions (Cheung et al., 2010).

PAHs have been measured in both modern diesel and gasoline engine exhaust (Zielinska et al., 2004; Cheung et al., 2010; Alkourdi et al., 2013; Huang et al., 2013; Herring et al., 2015; Muñoz et al., 2018) and have been recognized as carcinogenic for humans (IARC, 2010). Exposure to PAHs is associated with excess risk of lung cancer as well as other adverse health effects including bronchitis, asthma, heart disease, and reproductive toxicity (IARC, 2012, 2013, 2014). More recently, oxygenated and nitro-polycyclic aromatic hydrocarbons (OPAHs and NPAHs) have received increasing attention due to their cytotoxicity, immunotoxicity, carcinogenicity, and mutagenicity (Durant et al., 1996; IARC, 2012, 2013, 2014). Gasoline and diesel PM, and more specifically the ultrafine particle fraction (with diameter below $100 \mathrm{~nm}$ ), has been associated with an increased toxicity due to their higher surface area and greater ability to adsorb organic chemicals and metals (Mills et al., 2011; Cassee et al., 2013; Chen et al., 2016; Tyler et al., 2016).

Since 2012 the European market share of diesel light-duty vehicles has decreased to $35.9 \%$ of new vehicles' sales in 2018, while the demand for gasoline vehicles increased to $56.7 \%$ (ACEA, 2020). This trend continues regardless of the efficient PM (and BC) reduction achieved by diesel vehicles, due to the successful combination of diesel oxida- tion catalysts (DOCs) and diesel particulate filters (DPFs) (Tzamkiozis et al., 2010; Gordon et al., 2013; Platt et al., 2017). On the contrary, $\mathrm{NO}_{x}$ emissions from diesel still highly exceed those from gasoline vehicles (Wang et al., 2016; di Rattalma and Perotti, 2017). The market share of gasoline vehicles equipped with GDI systems is steadily increasing due to a better fuel efficiency and consequently lower $\mathrm{CO}_{2}$ emissions than in conventional port fuel injection (PFI) engines (Alkidas, 2007; Myung et al., 2012; Liang et al., 2013). In GDI engines, the fuel is injected at higher pressures and it is mixed less uniformly with the incoming air. As a consequence of this inhomogeneous combustion, these vehicles contribute to considerably higher emissions of $\mathrm{BC}$ and organic particles with diameters below $100 \mathrm{~nm}$, compared to those equipped with the PFI system (Karjalainen et al., 2014; Chan et al., 2014; Short et al., 2015; Zhu et al., 2016; Zimmerman et al., 2016; Platt et al., 2017; Saliba et al., 2017; Du et al., 2018). Gasoline vehicles also emit $\mathrm{NH}_{3}$ generated by three-way catalysts (TWCs) (e.g., Heeb et al., 2006; SuarezBertoa et al., 2014), which might highly enhance new particle formation in the environment (e.g., Korhonen et al., 1999; Ortega et al., 2008; Pikridas et al., 2012; Kürten, 2019).

Despite many studies investigating vehicle emissions in the past, non-regulated pollutants are still not well identified and quantified for recent vehicle technologies. European databases (such as COPERT 5) are missing information on PM chemical composition, preventing a full assessment of vehicle emission effects on urban air quality and health. This work provides a detailed description and comparison of PM emissions in terms of chemical composition and emission factors from three diesel and four gasoline (both GDI and PFI) commercial Euro 5 light-duty vehicles tested at a roll-bench chassis dynamometer facility. The chemical speciation of particulate matter included BC, organics, sulfate, ammonium, nitrate, and PAHs and was accomplished using real-time and high-resolution instrumentation, providing real-time emission profiles and information on the impact of after-treatment devices along the cycle. Particle morphology, surface structure, and elemental composition were furthermore investigated using offline analysis.

\section{Experimental}

\subsection{Vehicles and infrastructure}

Four gasoline and three diesel Euro 5 light-duty vehicles were investigated; their names and specifications are listed in Table 1. The passenger vehicles were either rented from a local car rental company or they were privately owned, and their mileage ranged from 9500 to $103000 \mathrm{~km}$. Three GDI and one PFI vehicle, all equipped with three-way-catalysts (TWCs), and three diesel vehicles equipped with diesel oxidation catalysts (DOCs) and diesel particulate filters (DPFs) were tested. Two diesel vehicles had a catalysed DPF (CDPF) 
and one had a fuel-borne catalyst (FBC-DPF). Commercial fuel was purchased from the same gas station to minimize the influence of fuel composition on emissions. Elemental composition of fuels and lubricant oils was analysed using inductively coupled plasma mass spectrometry (ICP-MS).

The experiments were carried out at the roll-bench chassis dynamometer owned by the Environment, Planning, Safety and Eco-design Laboratory (EASE) of the French Institute of Science and Technology for Transport, Development and Networks (IFSTTAR). Three types of dilution systems were used: (a) a constant volume sampler (CVS) and two VKL 10 Palas for vehicles D1 and GDI1, (b) a fine-particle sampler (FPS 4000, Dekati Ltd) with two dilution stages for vehicles D2 and GDI2, and (c) an ejector dilution of one stage (with hot air) for vehicles D3, PFI, and GDI3. The dilution ratios for each system were calculated based on $\mathrm{CO}_{2}$ concentrations and are provided in Table 1 . Three different dilution systems were used because the data presented in this study correspond to four different measurement campaigns conducted in different years with different experimental setups.

The emissions of vehicles D2 and GDI2 were tested using the Worldwide Harmonized Light Vehicles Cycle (WLTC), (Tutuianu et al., 2015), which is the official cycle for emissions legislation of Euro 6 vehicles, while the D1, D3, GDI1, GDI3, and PFI vehicles were evaluated using the Common Artemis Driving Cycles (CADC hereafter Artemis) (André, 2004), which allows the separate evaluation of the contributions of urban, rural, and motorway driving conditions.

A suite of instrumentation was deployed for the characterization of both particle- and gas-phase emissions. A stainlesssteel sampling line of $10 \mathrm{~mm}$ inner diameter and 5-6 $\mathrm{m}$ long was used. The line was heated at $80-120^{\circ} \mathrm{C}$ in order to reduce losses of the semi-volatile compounds (SVOCs) which were analysed by proton-transfer-reaction mass spectrometry (PTR-MS) and gas chromatography-mass spectrometry (GC-MS) techniques (Marques et al., 2021). The total flow was approximately of $60 \mathrm{~L} \mathrm{~min}^{-1}$. Before reaching the instruments, the line was split in two parts: one for the PM measurements, kept at room temperature, and a second one for the gas-phase measurements kept at $80-120^{\circ} \mathrm{C}$. In this work, we focus on the particle phase only.

\subsection{Instrumentation}

Four experimental campaigns were conducted using different combinations of measurement systems. Thus, the instrumentation configuration was not the same for all the vehicles tested (Table 1).

\subsubsection{HR-ToF-AMS and c-ToF-AMS}

An Aerodyne high-resolution time-of-flight aerosol mass spectrometer (HR-ToF-AMS) (DeCarlo et al., 2006) or a compact time-of-flight aerosol mass spectrometer (c-ToF-
AMS) (Drewnick et al., 2005) was deployed for the sizeresolved chemical composition analysis of the non-refractory species (e.g., organics, sulfate, ammonium, nitrate). The vaporizer temperature was set at $600-650^{\circ} \mathrm{C}$, and the tungsten filament for electron ionization was run at an accelerating voltage of $70 \mathrm{eV}$. The sampling time resolution was set between 20 and $40 \mathrm{~s}$ in $\mathrm{V}$-mode.

\subsubsection{Aethalometer and MAAP}

An Aethalometer AE 33-7 (Magee Scientific) or a multiangle absorption photometer (MAAP 5012, Thermo Fisher Scientific) was used for black carbon measurements at wavelengths of 670 and $880 \mathrm{~nm}$ respectively. The time resolution for the Aethalometer was between 1 and $10 \mathrm{~s}$, while for the MAAP is was between 2 and $5 \mathrm{~min}$. The MAAP data, when characterized by high $\mathrm{BC}$ mass concentrations, were corrected using the method proposed by Hyvärinen et al. (2013).

\subsubsection{Offline analysis: GC-MS}

Few off-line filters were used for PAH analysis using the GC-MS technique. The analysis was carried out on a trace GC Ultra (Thermo Scientific) equipped with a TG-5MS capillary column $(30 \mathrm{~m} \times 0.25 \mathrm{~mm}$ i.d., $0.25 \mu \mathrm{m}$ film thickness, Thermo Scientific) coupled to a TSQ Quantum XLS triplequadrupole mass spectrometer (Thermo Scientific). Helium was used as the carrier gas at a constant flow rate of $1 \mathrm{~mL} \mathrm{~min}{ }^{-1}$. A total of $1 \mu \mathrm{L}$ of the sample was injected in splitless mode. The GC oven temperature programme was set to start at $65^{\circ} \mathrm{C}$ and ramp to $200^{\circ} \mathrm{C}$ at a $6^{\circ} \mathrm{C} \mathrm{min}^{-1}$ rate and then to $300^{\circ} \mathrm{C}$ at $20^{\circ} \mathrm{C} \mathrm{min}^{-1}$, held for $20 \mathrm{~min}$. Temperatures of ion source, injector, and transfer line were maintained at $250^{\circ} \mathrm{C}$. The triple-quadrupole mass spectrometer was operated in a full-scan and single-ion monitoring mode at $70 \mathrm{eV}$ ionization energy. PAH calibration mixture and individual standards (EPA 610A, Restek; 9,10-anthraquinone, Chem Service; 1-methylnaphthalene, Sigma-Aldrich) were used for the identification and quantification of the target compounds.

\subsubsection{Off-line analysis: TEM-EDX and XPS techniques}

A mini-particle sampler (MPS) was used to collect exhaust particles. This technique, based on filtration through TEMporous grids (Holey carbon films and Quantifoil, AGAR Scientific), enables sampling of particles directly on a specific support, minimizing additional sample preparation procedure and sampling artefacts (R'Mili et al., 2013). The sampling was performed at specific times of the cycle, for example at the first minutes of the cold start or during a few minutes of the motorway cycle with a flow rate of $0.3 \mathrm{~L} \mathrm{~min}^{-1}$. The deposited particles were then investigated by transmission electron microscopy (TEM), coupled with energydispersive X-rays (EDX). Grids from the D1 and GDI1 vehicles were analysed using a JEOL 2010F microscope op- 
Table 1. Technical characteristics of the tested vehicles, experimental conditions, and particle-phase instrumentation used.

\begin{tabular}{llll|llll}
\hline & \multicolumn{3}{c}{ Diesel Euro 5 } & \multicolumn{3}{c}{ Gasoline Euro 5 } \\
\cline { 2 - 7 } Vehicle name & D1 & D2 & D3 & GDI1 & GDI2 & PFI & GDI3 \\
\hline Size class & 1.5 DCI & 1.6 TDI & 2.0 HDI & 1.2 TSI & 0.9 TCE & 1.0 VVTI & 1.2 TCE 16 V \\
Engine capacity $\left(\mathrm{cm}^{3}\right)$ & 1461 & 1598 & 1997 & 1197 & 900 & 998 & 1149 \\
Weight $(\mathrm{kg})$ & 1090 & 1262 & 1515 & 1320 & 1055 & 1030 & 1100 \\
Odometer mileage $(\mathrm{km})$ & 87073 & 78903 & 103000 & 25844 & 9500 & 27712 & 97089 \\
Catalyst type & DOC & DOC & DOC & TWC & TWC & TWC & TWC \\
Particulate filter type & CDPF & CDPF & FBC-DPF & - & - & - & - \\
Driving cycles tested & Artemis & WLTC & Artemis & Artemis & WLTC & Artemis & Artemis \\
Dilution system & CVS & FPS-4000 & Hot injector & CVS & FPS-4000 & Hot injector & Hot injector \\
Dilution ratio & $8-40$ & $7-12$ & $2.3-15$ & $13-100$ & $20-46$ & 2.3 & 1.5 \\
AMS type & c-ToF & c-ToF & HR-ToF & - & c-ToF & HR-ToF & HR-ToF \\
MAAP/AE-33 & MAAP & AE-33 & - & MAAP & AE-33 & - & AE-33 \\
CPC & Yes & Yes & - & Yes & Yes & Yes & Yes \\
FMPS/SMPS/SMPS+E & Yes & Yes & - & - & Yes & - & - \\
TEM/XPS & Yes/no & Yes/no & Yes/no & Yes/no & Yes/no & Yes/yes & - \\
\hline
\end{tabular}

erated at $200 \mathrm{kV}$, while all the other samples were analysed using a JEOL JEM2010 microscope, fitted with a LaB6 electron gun under a $200 \mathrm{kV}$ accelerating voltage and an edge-toedge resolution of $0.23 \mathrm{~nm}$ at $200 \mathrm{kV}$. The instrumentation included also an EDX spectrometer (BRUKER, Quantax) with an XFlash ${ }^{\circledR}$ silicon drift detector, which has a resolution of 65 and $73 \mathrm{eV}$ for the $\mathrm{K} \alpha$ transition of carbon and fluoride respectively.

Particles emitted by the PIF4 vehicle were further analysed by XPS recorded under an ultra-high vacuum using a Resolve 120 hemispherical electron analyser (PSP Vacuum) and an un-monochromatized X-ray source $(\mathrm{Mg} \mathrm{K} \alpha$ at $1253.6 \mathrm{eV}$, PSP Vacuum Technology) operated at $100 \mathrm{~W}$ at an incidence angle of $30^{\circ}$ with respect to the analyser axis. This X-ray excitation energy and detection geometry correspond to an analysed depth of about $1 \mathrm{~nm}$ at the $\mathrm{C} 1 \mathrm{~s}$ and O1s lines. Survey spectra were collected at a pass energy of $50 \mathrm{eV}$ and an energy step of $0.2 \mathrm{eV}$, while the other lines were collected at $20 \mathrm{eV}$ pass energy and a step of $0.1 \mathrm{eV}$. The XPS lines were deconvoluted with the CasaXPS programme, after Shirleytype or linear background subtraction. Quantitative estimations of the sample composition were done after correction by the relative sensitivity factors (RSFs) provided in the programme.

\subsection{Methods}

\subsubsection{Organics and PAHs}

The AMS data were analysed with SQUIRREL v1.60A and PIKA v1.20A with Igor Pro 6.37 (Wave-Metrics). For the organic species, we used the fragmentation table of Aiken et al. (2009). For the vehicles D1, D2, and GDI2 the mass spectra are provided in unit mass resolution (UMR), while for the vehicles D3, PFI, and GDI3 the mass spectra are given in high resolution (HR). Since the majority of the signal at $m / z 44$ was practically due to the gaseous $\mathrm{CO}_{2}$, the signal at $\mathrm{m} / \mathrm{z} 44$ was removed from the fragmentation table. In addition, we removed the $m / z 73,147,207,221$, and 281 as they were related to polydimethylsiloxane $\left(\mathrm{SiO}\left(\mathrm{CH}_{3}\right)_{2}\right)$ contaminations due to conductive silicone material present in parts of the tailpipe (Timko et al., 2009, 2014; Lamma, 2017). For the quantification of the aerosol and the PAH mass concentration, a collection efficiency (CE) of 1 was used following previous engine exhaust studies (Canagaratna et al., 2004; Slowik et al., 2004; Dallmann et al., 2014; Eriksson et al., 2014; Bruns et al., 2015; Herring et al., 2015). The relative ionization efficiency (RIE) of the PAHs was set to 1.4, as measurements of four PAHs resulted in an RIE between 1.35 and 2.1 (Slowik et al., 2004; Dzepina et al., 2007). PAH analysis was carried out using Herring et al. (2015) methodology for vehicles D3, PFI, and GDI3 (HR-ToF-AMS data). This method is based on laboratory intercomparison of PAHs measured by AMS and GC-MS (Dzepina et al., 2007). The method has been more recently applied for the identification and quantification of functionalized PAHs in wood-burning organic aerosol (Hartikainen et al., 2020). Briefly, each PAH compound concentration $\left(C_{i}\right)$ is estimated using the relative abundance (i.e., the signal fraction of the major contributing ion $\left.[\mathrm{M}-\mathrm{H}]^{+}\right)\left(f_{\mathrm{A}, i}\right)$ of the PAH molecular ion in the reference mass spectra and its molecular ion concentration $\left(C_{\mathrm{ion}, i}\right)$ (measured for single PAH compounds) by Eq. (1):

$C_{i}=\frac{C_{\mathrm{ion}, i}}{f_{\mathrm{A}, i}}$.

Even though for most of the PAHs the $f_{\mathrm{A}, i}$ is unknown, some laboratory-measured PAH spectra using the AMS do exist (Alfarra, 2004; Aiken et al., 2007; Dzepina et al., 2007). These spectra are for pyrene $\left(\mathrm{C}_{16} \mathrm{H}_{10}, \mathrm{~m} / z 202\right)$, fluoranthene $\left(\mathrm{C}_{16} \mathrm{H}_{10}, m / z\right.$ 202), 2,3-benzofluorene $\left(\mathrm{C}_{17} \mathrm{H}_{12}\right.$, 
$m / z$ 216), 1-methylpyrene $\left(\mathrm{C}_{17} \mathrm{H}_{12}, \mathrm{~m} / z\right.$ 216), triphenylene $\left(\mathrm{C}_{18} \mathrm{H}_{12}, \mathrm{~m} / z\right.$ 228), 10-methylbenz $[a]$ anthracene $\left(\mathrm{C}_{19} \mathrm{H}_{14}, \mathrm{~m} / z\right.$ 242), benzo[ $e$ ]pyrene $\left(\mathrm{C}_{20} \mathrm{H}_{12}, \mathrm{~m} / z\right.$ 252), and benzo[ghi]perylene $\left(\mathrm{C}_{22} \mathrm{H}_{12}, \mathrm{~m} / z\right.$ 276), and their relative abundance $\left(f_{\mathrm{A}, i}\right)$ is summarized in Herring et al. (2015). In this work we used the average relative abundance of the above-measured compounds, which corresponds to an $f_{\mathrm{A}, i}$ of $26.5 \%$. Using this assumption we introduce an error of $\pm 40 \%$ (taking into account the minimum and the maximum $f_{\mathrm{A}, i}$ reported for the AMS-measured PAH spectra). This value is very close to what was published by Dzepina et al. (2007), who showed that the Q-AMS capability of measuring particulate $\mathrm{PAH}$ in ambient air has uncertainty of $+35 \%$ and $-38 \%$. An example of the HR mass spectra fitting for naphthalene, methyl-naphthalene, anthracene, and nitro-anthracene is given in Fig. S1 in the Supplement.

Additional tests were conducted comparing AMS results with GC-MS analysis (quartz filters) of particle-bound PAHs emitted from the GDI3 vehicle (see Table S3). The GCMS analysis method of PAHs is derived by previous works carried out on atmospheric particulate matter samples by El Haddad et al. (2011) and El Haddad (2011). The filter samples were spiked with known amounts of the isotope labelled standard anthracene d10 (Sigma-Aldrich) and they were introduced in a $66 \mathrm{~mL}$ stainless-steel cell. Accelerated solvent extraction was carried out with a dichloromethane-acetone mixture $(1: 1 \mathrm{v} / v$, high-performance liquid chromatography (HPLC) grade, Sigma-Aldrich) using an ASE 350 system (Dionex) at $100^{\circ} \mathrm{C}$ and 100 bar. The extracts were purged from the cell using pressurized nitrogen gas for $100 \mathrm{~s}$. The extracts were then concentrated under a gentle nitrogen gas stream at $40^{\circ} \mathrm{C}$ (TurboVap II, Biotage) down to a volume of $500 \mu \mathrm{L}$ in hexane (HPLC grade, Sigma-Aldrich).

\subsubsection{Emission factors}

The distance-based emission factor (EF) of each species during the cycle was calculated using Eq. (2):

$\mathrm{EF}=\frac{\mathrm{DR}}{D} \int C(t) * Q_{\mathrm{ex}}(t) \cdot \mathrm{d} t$,

where $C(t)$ is the mass concentration of the pollutant (after background corrections), $Q_{\mathrm{ex}}(t)$ is the exhaust flow rate at the tail pipe measured by the CVS or the FPS, DR is the external dilution ratio before the entrance of the instrumentation, and $D$ is the distance of the cycle $(4.51 \mathrm{~km}$ for Artemis urban cycle, $23.8 \mathrm{~km}$ for Artemis motorway cycle, and $23.25 \mathrm{~km}$ for WLTC).

\section{Results}

\subsection{AMS chemical composition}

\subsubsection{Time series profiles}

Figure 1 shows the particle mass concentration transient profile of $\mathrm{BC}$ measured by an Aethalometer and those of organics, sulfate, nitrate, and ammonium measured by the HRToF-AMS for the GDI3 vehicle during Artemis cold urban, hot urban, and motorway cycles. The mass concentrations have been corrected for the dilution. The particle-phase emissions were mainly composed of BC $(96.8 \%-98 \%)$, while the organic fraction accounted for 1.9\%-3.1\%; ammonium, sulfate, and nitrate were approximately $0.1 \%$. The highest mass concentrations of $\mathrm{BC}$ and organics, $120 \mathrm{mg} \mathrm{m}^{-3}$ and $1600 \mu \mathrm{g} \mathrm{m}^{-3}$ respectively, were observed during the first 1 2 min of the cycle, due to the cold engine and thus low catalyst efficiency, which is in agreement with previous studies (e.g., Weilenmann et al., 2009; Clairotte et al., 2013; Collier et al., 2015; Karjalainen et al., 2016; Louis et al., 2016; Pieber et al., 2018). GDI2 particulate mass concentrations in the exhaust flow were measured during WLTC (Fig. S2): BC contributed $83 \%-98 \%$ to the total PM mass, while the organic fraction ranged from $1.8 \%$ to $14 \%$ of the PM. The remaining fraction $0.2 \%-3 \%$ was composed of ammonium, sulfate, and nitrate. For GDI2 the emitted PM concentrations were comparable to the values measured for the GDI3 vehicle during the Artemis cold urban cycle.

PM emissions from the PFI vehicle are shown in Fig. S3. The organic and nitrate mass concentrations were a factor of 8 and 2 lower with respect to the GDI3 vehicle during the cold urban cycle. High PM emissions from GDI technology have been reported in several previous studies (e.g., Zhu et al., 2016; Saliba et al., 2017; Du et al., 2018) and were explained by the incomplete volatilization and mixing of the fuel in the combustion chamber (Fu et al., 2014; Chen et al., 2017; Saliba et al., 2017).

Figure 2 shows the PM emissions from the D1 vehicle (equipped with a CDPF) in terms of chemical composition (Fig. 2a) and particle size distribution (Fig. 2b and c) during a cold urban cycle and three consecutive motorway cycles. The cold cycle was characterized by relatively high BC and organic matter emissions, reaching concentrations of 300 and $50 \mu \mathrm{g} \mathrm{m}^{-3}$ respectively. During the cold urban cycle BC accounted for $94 \%$ of the total mass concentration and organics only for $4 \%$; during the motorway cycle the contribution of BC decreased to $85 \%$, while ammonium bisulfate increased to $(6 \%)$ and organics to $(8 \%)$. The three motorway cycles showed good repeatability, characterized by a first release of $\mathrm{BC}$ followed by emissions of ammonium bisulfate and organic nanoparticles (of $15 \mathrm{~nm}$ mean diameter). The identification of ammonium bisulfate was based on the sulfate / ammonium mass concentration ratio. These emissions were interpreted as a passive regeneration of the DPF occur- 


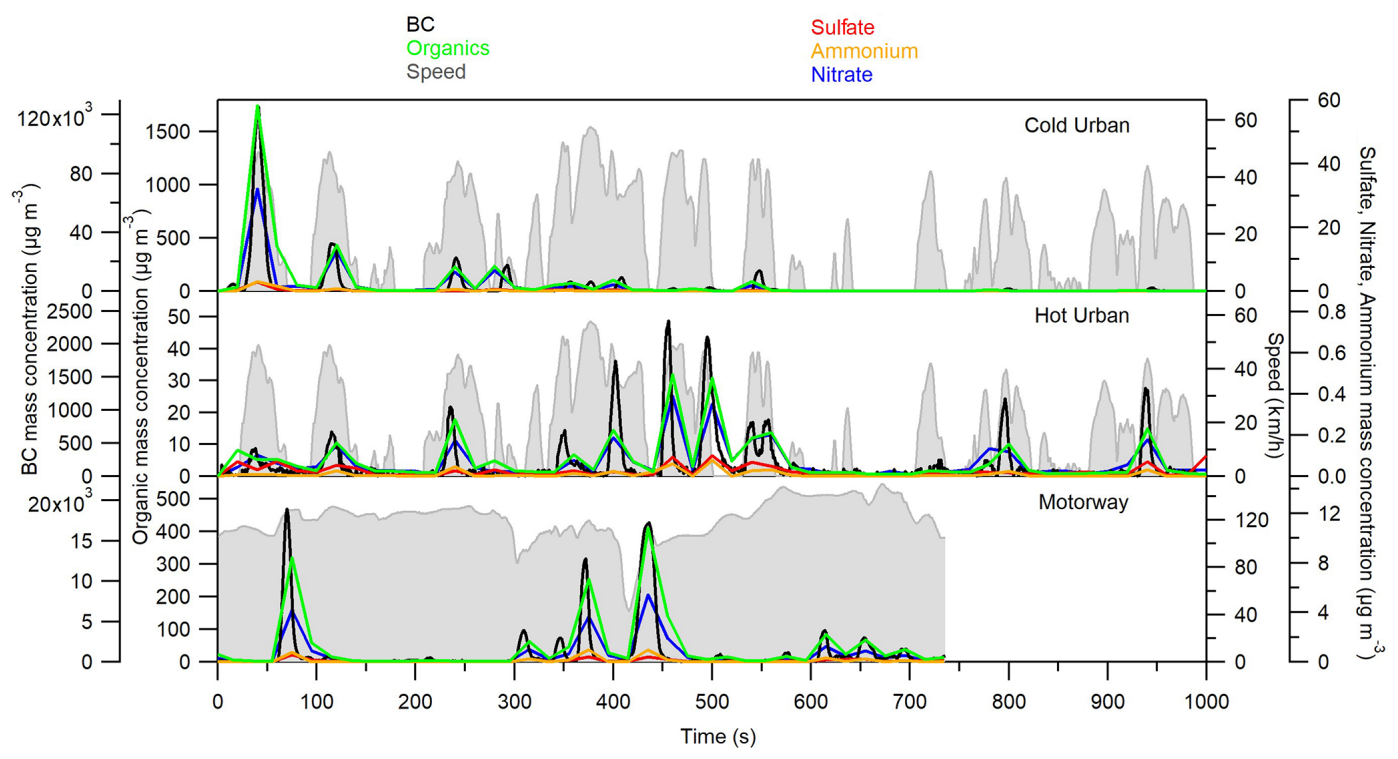

Figure 1. BC, organics, sulfate, nitrate, and ammonium time profiles during a cold urban, a hot urban, and a motorway Artemis cycle for the GDI3 vehicle.

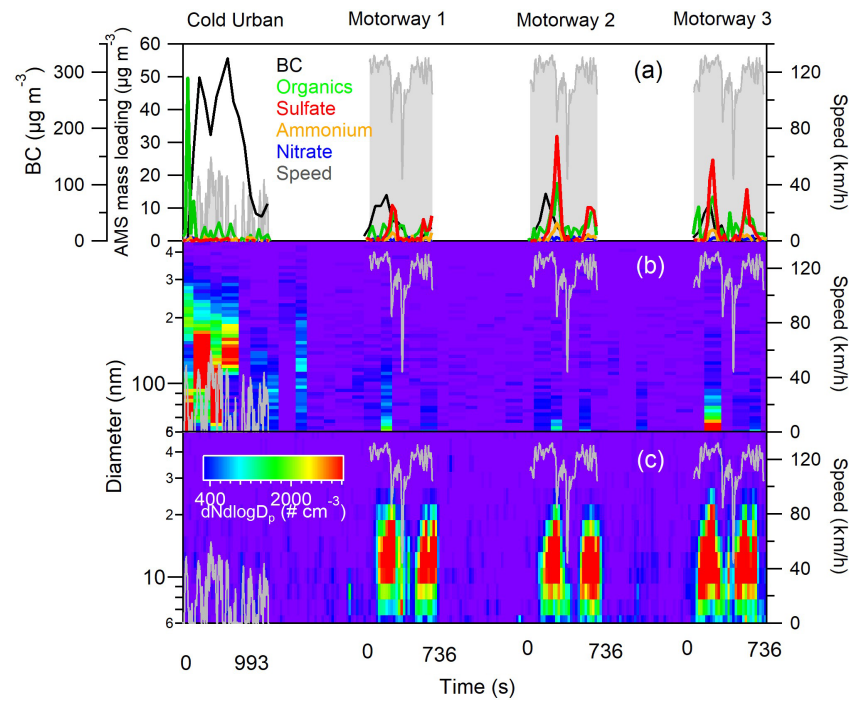

Figure 2. PM emissions from the D1 vehicle, during a cold urban cycle and three successive motorway cycles: (a) AMS major chemical species and BC (MAAP), (b) size distribution of fine particles (SMPS), and (c) size distribution of ultrafine particles (SMPS+E).

ring at the high temperatures reached during the cycle. The same behaviour was previously reported for diesel vehicles equipped with CDPF (R'Mili et al., 2018).

PM emission profiles during WLTC cycles from a second CDPF vehicle (D2) are shown in Fig. S4. This vehicle was characterized by very low emissions, demonstrating the efficiency of diesel after treatment devices (DPF). Emissions were observed during few accelerations; the organic mass concentration always remained below $20 \mu \mathrm{g} \mathrm{m}^{-3}$, while am- monium bisulfate concentrations reached maximum values of $50 \mu \mathrm{g} \mathrm{m}^{-3}$.

The emission of sulfate-containing particles from the two CDPF vehicles was explained by the presence of the catalyst on the DPF walls. It has been proposed that during acceleration and hot-engine combustion periods sulfur can be released from the DPF and converted into $\mathrm{SO}_{3}$ by the catalyst, forming successively sulfuric acid and/or ultrafine bisulfate/sulfate ammonium particles (e.g., Bikas and Zervas, 2007; Bergmann et al., 2009; Arnold et al., 2012; R'Mili et al., 2018).

PM emissions from the D3 vehicle equipped with an FBC catalyst (Fig. S5) were relatively high: organic aerosol, nitrates, and sulfate reached 300,90 , and $40 \mu \mathrm{g} \mathrm{m}^{-3}$ respectively. The high PM concentrations were interpreted as a possible failure in the after-treatment system and will be further discussed in Sect. 3.3. This was supported by the relatively higher emissions of $\mathrm{CO}_{2}, \mathrm{CO}, \mathrm{NO}_{x}$, and total hydrocarbons (THCs) in comparison to the rest of the diesel vehicles (Table S1).

\subsubsection{Organic mass spectra}

Figure 3 shows the HR-AMS mass spectra for the GDI3 and the D3 vehicles during the first 2 and last $2 \mathrm{~min}$ of each type of cycle (cold urban, hot urban, and motorway). The mass spectra were characterized by the ion fragments $\mathrm{C}_{n} \mathrm{H}_{2 n+1}^{+}(m / z=29,43,57,71,85 \ldots)$ typical of saturated alkyl compounds ( $n$-alkanes and branched alkanes), $\mathrm{C}_{n} \mathrm{H}_{2 n-1}^{+}(m / z=27,41,55,69,83,97 \ldots)$ typical of unsaturated aliphatic compounds (cycloalkanes, alkenes), and $\mathrm{C}_{n} \mathrm{H}_{2 n-3}^{+}(m / z=67,81,95,109 \ldots)$ typical of bicycloalkanes and alkynes (McLafferty and Turecek, 1993). These spectra 
were consistent with the signatures found in both gasoline and diesel exhaust emissions (e.g., Canagaratna et al., 2004; Mohr et al., 2009; Chirico et al., 2011; Platt et al., 2013; Collier et al., 2015; Dallmann et al., 2014; R'Mili et al., 2018) and arise from unburned fuel, lubricating oil, and their partially oxidized products (Maricq, 2007).

During some periods of the cycle, the $m / z$ ratios of $43 / 41$, $57 / 55$, and $71 / 69$ were relatively high with values of 1.50 , 1.72, and 1.19 during the GDI3 cold start (Fig. 3a) and 1.30, 1.32, and 0.85 during the D3 hot-engine regimes (Fig. 3b). Comparing our mass spectra with pure gasoline, diesel fuel, and lubricant oil mass spectra analysed with a similar instrument (R'Mili et al., 2018), and knowing that the fuels contain high concentrations of $n$-alkanes, while lubricating oils tend to contain mostly cycloalkanes (Tobias et al., 2001; Isaacman et al., 2012), we concluded that both GDI3 and D3 vehicles emitted some oil (see also Sect. 3.2 for TEM images). However, we did not observe any evident correlation between oil droplet emissions and engine load or cycle speed or acceleration.

Hydrocarbon ion fragments accounted for $77 \%$ to $90 \%$ of the OA fraction for the GDI3 (Fig. 3a), for $83 \%-88 \%$ for the D3 (Fig. 3b), and for 56\%-87\% for the PFI vehicles (Fig. S6). Similar mass spectra were observed for the GDI2 and D1 vehicles (Figs. S7 and S8, UMR mass spectrum). The OA concentration emitted from the D2 vehicle was very low, and thus the corresponding AMS mass spectrum was associated with high uncertainty.

For all gasoline vehicles, sulfur-containing organic fragments at $m / z 45\left(\mathrm{CHS}^{+}, 44.979\right), 46\left(\mathrm{CH}_{2} \mathrm{~S}^{+}, 45.987\right)$, and $47\left(\mathrm{CH}_{3} \mathrm{~S}^{+}, 46.995\right)$ were detected. They accounted for approximately $2 \%-4 \%$ of the organic mass fraction for the GDI3 (Fig. 3a) and 6\%-7\% of the organic mass for the PFI (Fig. S7). For the GDI2 vehicle (Fig. S5), a high $m / z 45$ contribution was detected at the beginning of the hot-start WLTC, but the spectrum was acquired with a c-ToF-AMS, and therefore the signal can be assigned to both oxygenated $\left(\mathrm{CHO}_{2}^{+}\right.$and $\left.\mathrm{C}_{2} \mathrm{H}_{5} \mathrm{O}^{+}\right)$and organosulfur $\left(\mathrm{CHS}^{+}\right)$fragments. Sulfur-containing ion fragments were mostly emitted from hot engines (end of urban cycle and motorway cycle) and are tentatively explained by the release of some lubricant oil. Except for the above differences (presence of oil droplets and sulfur-containing fragments), no other significant variability was observed between the cold- and the hot-start HR mass spectra.

Table 2 presents the correlations between the mass spectra of the tested vehicles and those of previous studies (AMS mass spectra database). A very good correlation was found between the mass spectra from diesel and gasoline vehicles (Canagaratna et al., 2004; Mohr et al., 2009; R'Mili et al., 2018) and positive matrix factorization (PMF) factors related to fresh traffic emissions (Mohr et al., 2012; Kostenidou et al., 2015; Kaltsonoudis et al., 2017). The $R^{2}$ ranged between 0.72 and 0.92 (Table 2) for all cases.

\subsubsection{PAHs}

In total, 45 PAHs were identified for the GDI3, PFI, and D3 vehicles during Artemis cycles (Table S2). The PAH identification and quantitative estimation were based on Herring et al. (2015) and Dzepina et al. (2007) methods. An additional test was carried out comparing AMS results with GC-MS analysis of particles collected on quartz filters for the GDI3 vehicle. Table S3 presents the intercomparison of PAH concentrations between AMS and GC-MS. Three cumulative cycles (one hot urban and two motorway) were collected on the filter. A considerable overestimation for AMS results is observed for light PAHs, which is reduced for heavier PAHs, while a good agreement is found for oxy-PAHs. Filter sampling could be affected by volatilization due to the warm flow (20 L min ${ }^{-1}$ ) since the line was heated, and only the last few metres were kept at room temperature.

The PAH mass concentrations during the cold cycle were considerably higher for GDI3 and D3 than for PFI, with values of $1.66,2.21$, and $0.47 \mu \mathrm{g} \mathrm{m}^{-3}$, correspondingly. Slightly lower mass concentrations were observed during the hot cycles. For the diesel D1 and D2 vehicles, the PAH signal was close to the detection limit, demonstrating the efficiency of diesel after-treatments devices (DOC and DPF). The remarkable difference among the three diesel vehicles suggests that D3 indeed presented a failure in the after-treatment device. For the GDI2 vehicle, the identification of individual PAHs was not possible since the data were collected with a c-ToFAMS (UMR mass spectra).

Figure 4 presents the relative contribution of five PAHs families for the GDI3, PFI, and D3 vehicles: unsubstituted PAHs (UnSubPAHs), methylated PAHs (MPAHs), oxygenated PAHs (OPAHs), nitro-PAHs (NPAHs), and amino PAHs (APAHs). The UnSubPAHs represented the most abundant group, accounting for 52 to $66 \%$ of the total PAHs, followed by MPAHs (14\%-35\%), then OPAHs (5\%-19\%), NPAHs (1\%-11\%), and finally APAHs (1\%-6\%). Table S4 shows the individual PAH fractions during cold- and hot-start cycles. Naphthalene emissions dominated, contributing from $9.6 \%$ to $19.1 \%$ of the total PAHs, which is in agreement with previous studies (e.g., de Abrantes et al., 2004; Vouitsis et al., 2009; Huang et al., 2013; Alves et al., 2015; de Souza and Corrêa 2016; Muñoz et al., 2018; Yang et al., 2018). Among the three-ring PAH species, acenaphthylene (4.3\%-9.7\%), anthracene, and its isomer phenanthrene (4.1\%-15.9\%) were the most abundant; concerning the four-ring PAHs, the major contribution was from pyrene and from the isomers fluoranthene and acephenanthrylene (1.3\%-13.9\%). Among the five-ring PAHs, benzo[ $a]$ pyrene and all its isomers $(0.4 \%-3.8 \%)$ and benzo[ $g h i]$ fluoranthene $(1 \%-3.3 \%)$ were the most significant compounds. Some heavier PAHs such as indio[1,2,3-cd]pyrene, its isomer benzo[ $\mathrm{ghi}]$ perylene $(0.4 \%-6.6 \%)$, and coronene $(0.06 \%-5.3 \%)$ were mostly found in gasoline vehicle emissions. Light PAHs have often been measured in exhaust particles of light-duty vehicles 

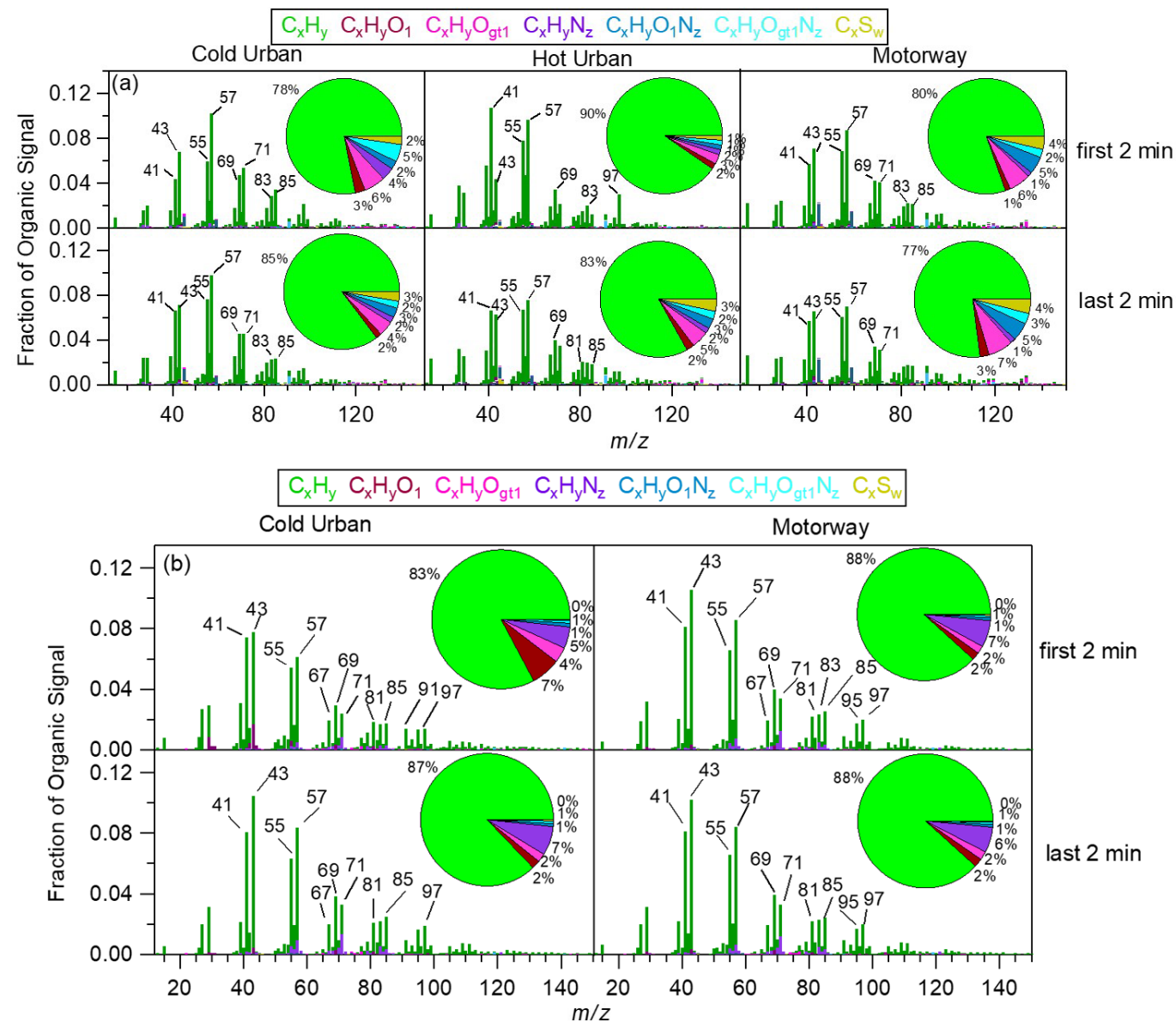

Figure 3. HR mass spectra and chemical composition: (a) during the first 2 and the last 2 min of a cold urban (left), hot urban (middle), and motorway (right) Artemis cycle for the gasoline GDI3 vehicle and (b) during the first 2 and the last 2 min of a cold urban (left) and a motorway (right) Artemis cycle for the diesel D3 vehicle.

Table 2. Correlations between mass spectra taken during the first 2 min of an Artemis motorway cycle and mass spectra from diesel and gasoline vehicles, lubricant oil, and PMF factors related to fresh transportation (HOA, hydrocarbon-like OA) from selected studies using both $R^{2}$ and the angle $\theta$ (Kostenidou et al., 2009) in parentheses. The angle $\theta$ provides a better comparison for small differences in the mass spectra (when $R^{2}$ is less than 0.97 ), as this method treats the mass spectra as vectors. More details about this method are given in Kostenidou et al. (2009).

\begin{tabular}{lccccc}
\hline & \multicolumn{4}{c}{ First 2 min of Artemis motorway $\left(R^{2}\right.$ and angle $\theta$ in degrees $)$} \\
\cline { 2 - 6 } & D1 & D3 & GDI2 & PFI & GDI3 \\
\hline Diesel bus exhaust $^{1}$ & $0.80(24.9)$ & $0.97(9.1)$ & $0.88(19.1)$ & $0.88(19.8)$ & $0.92(15.1)$ \\
Diesel truck $^{2}$ & $0.76(27.4)$ & $0.95(12.2)$ & $0.84(21.8)$ & $0.83(23.1)$ & $0.90(16.8)$ \\
Gasoline car $^{2}$ & $0.74(28.2)$ & $0.96(11.2)$ & $0.83(22.9)$ & $0.81(25.7)$ & $0.91(16.8)$ \\
Diesel vehicle Euro 5 $^{3}$ & $0.82(23.6)$ & $0.77(26.9)$ & $0.83(22.5)$ & $0.72(29.2)$ & $0.73(28.9)$ \\
Lubricant oil (diesel vehicle) $^{3}$ & $0.75(28.8)$ & $0.96(12.3)$ & $0.86(21.5)$ & $0.80(27.9)$ & $0.89(19.4)$ \\
HOA Athens summer & $0.73(29.3)$ & $0.95(12.3)$ & $0.80(24.8)$ & $0.83(23.9)$ & $0.91(16.8)$ \\
HOA ICE-HT winter & $0.69(31.9)$ & $0.94(12.7)$ & $0.77(26.8)$ & $0.80(24.0)$ & $0.91(16.8)$ \\
HOA Barcelona & $0.77(27.2)$ & $0.96(10.8)$ & $0.85(21.6)$ & $0.84(24.3)$ & $0.92(16.2)$ \\
\hline
\end{tabular}

${ }^{1}$ Canagaratna et al. (2004). ${ }^{2}$ Mohr et al. (2009). ${ }^{3}$ R'Mili et al. (2018). ${ }^{4}$ Kostenidou et al. (2015). ${ }^{5}$ Kaltsonoudis et al. (2017).

${ }^{6}$ Mohr et al. (2012). 


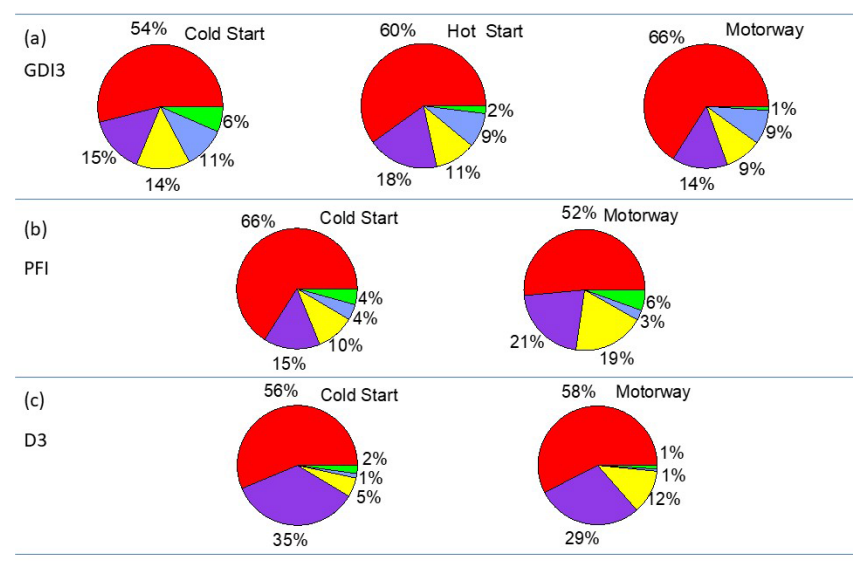

UnSUbPAH MPAH OPAH NPAH APAH

Figure 4. Average contribution of the various PAH families during Artemis cycles for GDI3 (a), PFI (b), and D3 (c) vehicles, using the method of Herring et al. (2015).

(Ravindra et al., 2008; de Souza and Corrêa, 2016; Muñoz et al., 2018; Yang et al., 2018), and their presence has been tentatively explained by incomplete fuel combustion (LeaLangton et al., 2008; Ravindra et al., 2008) since these compounds are present in the fuel composition (Marr et al., 1999; de Souza and Corrêa, 2016). During the gasoline hot cycles an increase in the three- and four-ring PAH (anthracene, pyrene, paracyclene, and all its isomers) contribution was observed.

MPAHs accounted for $14 \%$ to $35 \%$ of the total PAHs and were more abundant for the D3 vehicle; major contributions arose from methyl- and dimethyl-naphthalene, methylphenanthrene, methyl-fluorene, and ethyl-phenanthrene, which is in agreement with Muñoz et al. (2018) and Yang et al. (2018). All these compounds have been recently associated with carcinogenic potency (Samburova et al., 2017). BaP and its isomers (benzo[b]fluoranthene, benzo $[j]$ fluoranthene, or benzo $[k]$ fluoranthene) contributed only $0.5 \%$ to $7 \%$ of the PAH fraction of gasoline cars (taking into account the AMS and the GC-MS analysis), while the signal was below the detection limit in the D3 emissions. Yet, recent studies suggest that $\mathrm{BaP}$, as an indicator compound, may highly underestimate the total carcinogenic potency of PAH mixtures (Samburova et al., 2017).

Figure 5 depicts the transient profile of selected PAHs for the GDI3, PFI, and D3 vehicles during Artemis cycles; these PAHs have been classified as carcinogenic or/and photomutagenic (compounds that cause mutagenicity after being exposed to visible or UV light) according to IARC 2010. Following BC and organic emission trends, PAHs were mostly emitted in the first few minutes of the cold urban cycle and during acceleration periods of the motorway cycle or during fuel-rich combustion periods in agreement with previous studies (Muñoz et al., 2018). The mass fractions of these carcinogenic and/or photomutagenic PAHs accounted for $27 \%-$
$49 \%$ for the GDI3, $29 \%-30 \%$ for the PFI, and $29 \%-31 \%$ for the D3 vehicles.

A considerable fraction - up to $31 \%$ of the total PAHs - was functionalized and included OPAHs, NPAHs, and APAHs. All technologies emitted an important fraction of OPAHs (up to 19\%); anthraquinone, indanone, and fluorenone were the most abundant in agreement with previous emission studies (Karavalakis et al., 2011) followed by dibenzofuran and dibenzopyran.

APAHs accounted for $1 \%$ to $6 \%$ of the total PAH fraction and were mostly emitted by gasoline cars. Major APAHs were aminopyrene/carbazole and dibenzocarbazole/aminobenzopyrene; however very little is known about the vehicle tailpipe emissions of these compounds so far.

Nitro-anthracene and its isomer nitro-phenanthrene contributed up to $8 \%$ of the total PAHs in the GDI3 emissions, but only $1 \%$ in PFI and D3 vehicles. Nitro-fluorene, nitropyrene, and nitro-chrysene were found in the vehicle exhaust of all three vehicles and accounted for less than $1 \%$ of the total PAH mass fraction. Similar results are reported by Yang et al. (2018) even though the authors found several nitronaphthalenes to be the major contributors to NPAH emissions. Even if present in small amounts, some of these compounds, such as 6-nitrochrysene and 1-nitropyrene, are classified as possibly carcinogenic to humans (group 2B) (IARC, 2012; Bandowe and Meusel, 2017). Surprisingly, NPAHs, including nitro-pyrene, were considerably higher in Euro 5 GDI emissions than in those of diesel vehicles, questioning the pertinence of using NPAHs such as 1-nitropyrene as markers of diesel emissions (Keyte et al., 2016).

\subsection{TEM and XPS analysis}

Figure 6 presents TEM images of particles emitted by the different cars during cold and motorway cycles. Figure 6a$\mathrm{c}$ and $\mathrm{d}-\mathrm{f}$ show particles emitted from the GDI1 and GDI2 vehicles; the samples were collected during the first $120 \mathrm{~s}$ of the cycle, and the dilution was around 40-46. Figure $6 \mathrm{~g}-\mathrm{i}$ show three images of particles emitted by the D1 vehicle; the corresponding sample was collected for $300 \mathrm{~s}$, and the dilution was around 40. TEM images confirmed the quite higher emissions of soot particles (or BC) for the two GDIs with respect to the diesel vehicles, which is in agreement with $\mathrm{BC}$ emissions measured by the MAAP and the Aethalometer. As usually mentioned in the literature, soot particles are observed either as fractal branched chains or as bigger agglomerates made of primary soot spheres of different sizes (Lapuerta et al., 2020). Primary soot particles with a diameter of $24.2 \pm 4.1 \mathrm{~nm}$ were observed for the gasoline vehicles during cold cycles (Fig. 6c and f), while the diameter was significantly smaller $(14.5 \pm 3.4 \mathrm{~nm})$ during hot cycles (Fig. S9c and f). The results are in a good agreement with previous literature, which reported primary diesel soot particles with a diameter in the range between 20-25 nm (Barone et al., 2012) and smaller sizes down to $16 \mathrm{~nm}$ (Mathis et al., 


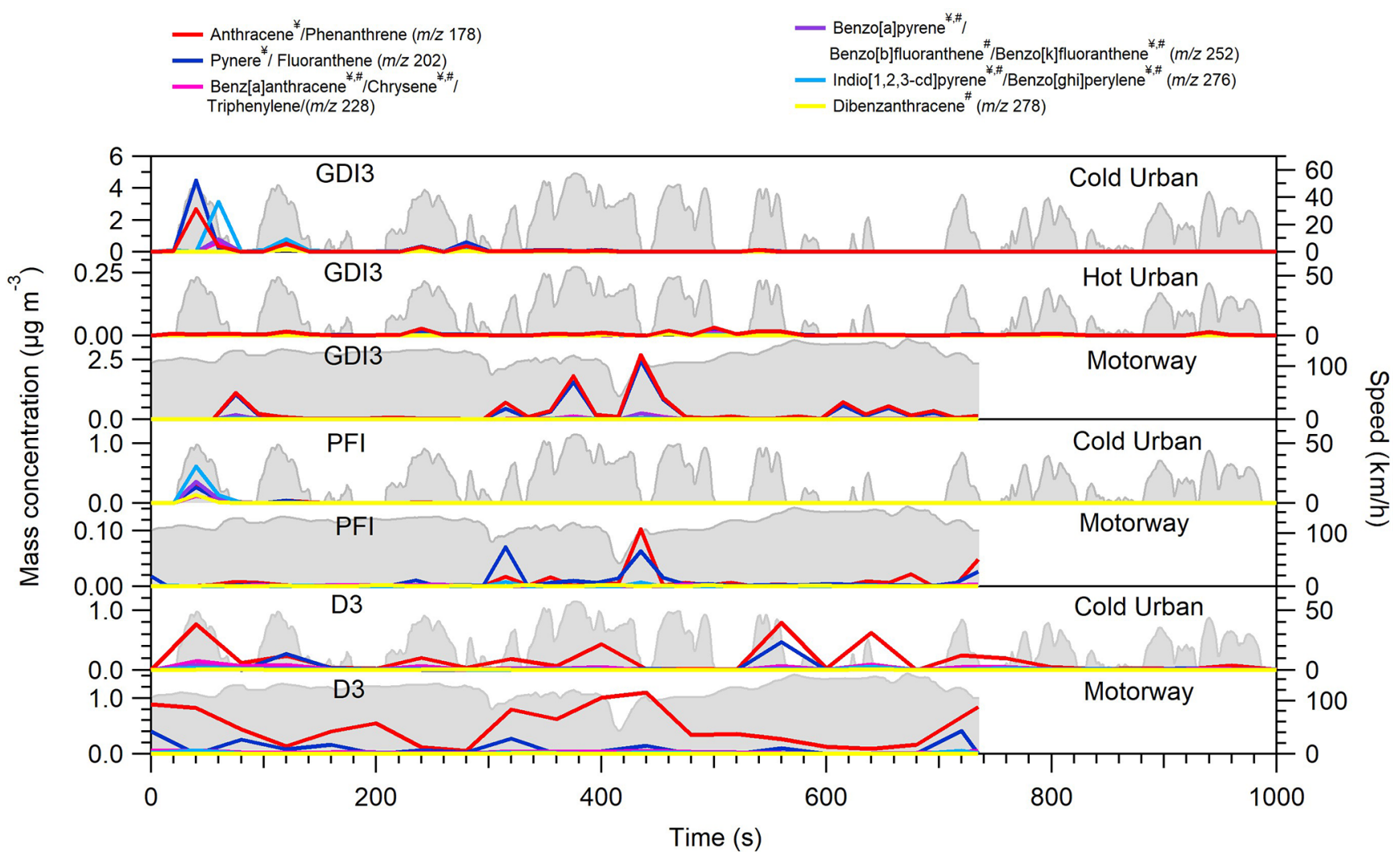

Figure 5. Example of PAH time series profiles for GDI3, PFI, and D3 vehicles for Artemis-tested cycles. The time series have been corrected for the injector dilution (1.5) and for a relative abundance $f_{\mathrm{A}, i}=0.265$. Compounds labelled with $¥$ have been characterized as photomutagenic, while compounds labelled with \# have been found to be cancerogenic (IARC, 2010). The identification and the quantification of their concentration are based on the approach of Herring et al. (2015).

2004; Gaddam and Vander Wal et al., 2013) for gasoline exhaust particles. A slight decrease in the primary particle size with increasing temperature was observed, in agreement with recent studies (Cadrazco et al., 2019). It has been shown that the engine load has no effect on soot morphology (Lapuerta et al., 2020) as many other parameters may favour opposite trends and compensate for each other. Indeed, a higher fuel / air ratio would tend to extend primary particle growth, while a higher engine temperature would favour their oxidation and thus lead to smaller particle sizes (Ye et al., 2014). Similarly, increasing the injection timing leads to a decrease in primary particle size due to an increase in in-cylinder oxidation time (Xu et al., 2014). It is therefore difficult to unambiguously attribute the slight decrease in particle size to the temperature effect only.

Figure 61 depicts soot particles from the D3 vehicle; tiny sparse dark spots were ubiquitous within the soot particles and were interpreted as metal inclusions. Unfortunately, EDX could not reveal their chemical nature due to the very small amount of material in these inclusions as they were very small (typically less than $0.5 \mathrm{~nm}$ ), and their spatial density was low. Nevertheless, we suppose that these inclusions were metallic and resulted from the after-treatment device of the FBC-DPF vehicle (D3), which uses metallic salts or organometallic additives into the engine combustion chamber. Upon combustion, the additive produces metal oxide nanoparticles that are mixed with soot particles and are deposited on the DPF walls. The role of these metals is to reduce the temperature during the DPF regeneration (Ntziachristos et al., 2005; Majewski and Khair, 2006; Song et al., 2006). When the exothermic oxidation of soot takes place, DPF filtration efficiency is considerably reduced, allowing, for a few minutes, emission of the ash particles attached to/or enclosed in soot particles (Liati et al., 2018).

The GDI2 (Figs. 6d-e, S9d-e) and D1 (Fig. 6i) vehicles emitted some droplets. They were observed during both cold and warm cycles, and they had variable sizes and shapes ranging from $100 \mathrm{~nm}$ to almost $1 \mu \mathrm{m}$. EDX analysis revealed that $\mathrm{C}$ and $\mathrm{O}$ were the major components, followed by $\mathrm{S}$. Minor components also included calcium, phosphorus, sodium, and silica. Only minor traces of zinc, iron, copper, chromium, aluminium, and nickel were observed. Analysis of the lubricant oils for D1, D2, GDI1, and GDI2 are presented in Table S5. Sulfur accounted for $0.12 \mathrm{wt} \%$ and $0.14 \mathrm{wt} \%$ of the lubricant oil. Other components of the lubricant oil were calcium, phosphorus, and zinc, and only traces of iron, silica, 


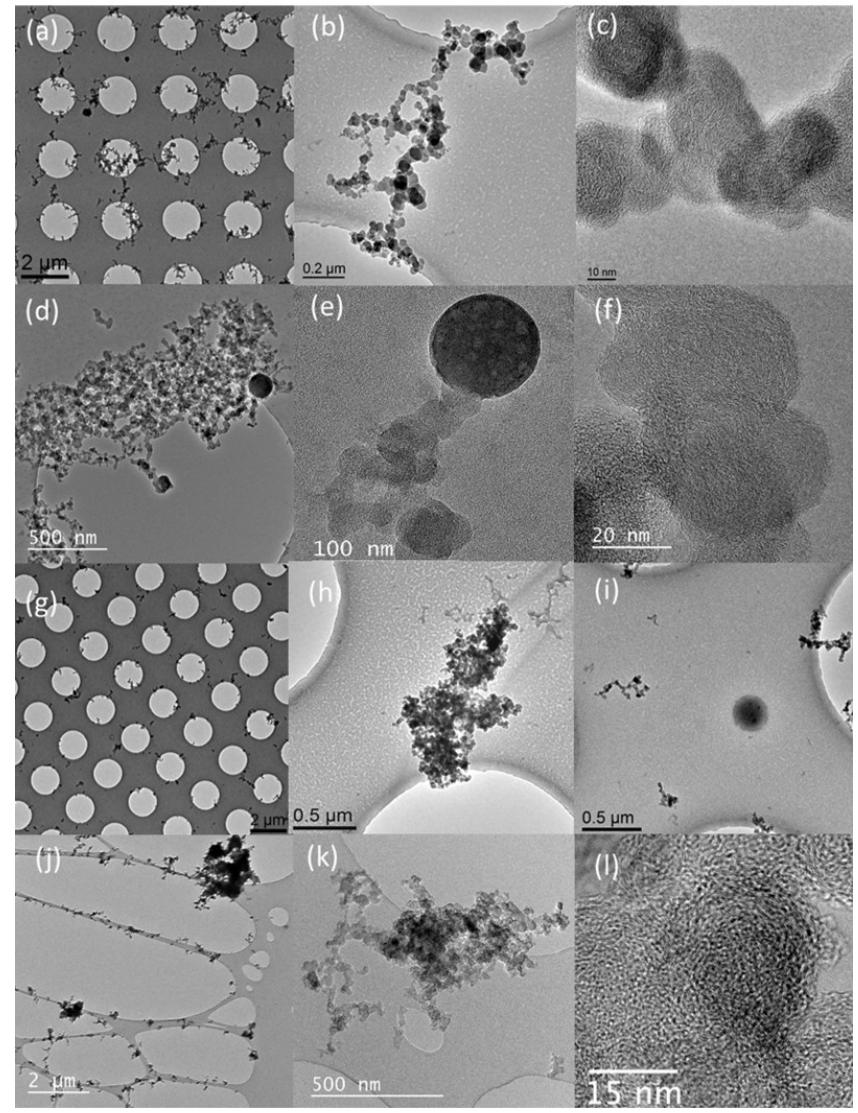

Figure 6. TEM images of samples collected during Artemis urban cold cycle: (a-c) GDI1 vehicle (dilution ratio 40), the sample was collected during the first $120 \mathrm{~s}$ of the cycle; (d-f) GDI2 vehicle (dilution ratio 46), the sample was collected during the first $120 \mathrm{~s}$ of the cycle; (g-i) D1 vehicle (dilution ratio 40), the sample was collected during the first $300 \mathrm{~s}$ of the cycle and during the Artemis motorway cycle; (j-l) D3 sampling the first $45 \mathrm{~s}$ of the motorway cycle (dilution ratio 2), tiny metallic inclusions are observed in panel (l).

and copper were found. The iron found in the used lubricant oil suggests erosion or wear of the engine and exhaust line for both D1 and GDI1 vehicles. These findings are in line with previous studies that reported emissions of lubricant oil particles during transient driving conditions (Karjalainen et al., 2014; Rönkkö et al., 2014).

Particles emitted by the PFI vehicle were analysed by XPS. Figure S10a shows the survey spectrum, from which the averaged elemental composition of the sample was derived (wt \%). We noticed a strong $\mathrm{C} 1 \mathrm{~s}$ line at $285 \mathrm{eV}$ (53.8 wt \%), a strong $\mathrm{O} 1 \mathrm{~s}$ line at $530 \mathrm{eV}(23.9 \mathrm{wt} \%)$, and weaker signals of Ti-2p doublet at $460 \mathrm{eV}(8.3 \mathrm{wt} \%)$, zinc Auger lines $(265 \mathrm{eV}, 3.6 \mathrm{wt} \%)$, calcium $\mathrm{Ca} 2 \mathrm{p}(352 \mathrm{eV}$, $2.8 \mathrm{wt} \%)$, silicon $\mathrm{Si} 2 \mathrm{p}(110 \mathrm{eV}, 2.5 \mathrm{wt} \%)$, and phosphorus P2p $(140 \mathrm{eV}, 1.5 \mathrm{wt} \%)$. Other trace signals $(<1 \mathrm{wt} \%)$ of chlorine $\mathrm{Cl} 2 \mathrm{p}(200 \mathrm{eV})$, nitrogen N1s $(400 \mathrm{eV})$, silver Ag 3d $(374 \mathrm{eV})$, and sulfur S 2p (168 eV) are also observed. From previous (unpublished) SEM-EDX analysis we know that $\mathrm{Si}$ is an artefact coming from the support plate while $\mathrm{C}, \mathrm{N}, \mathrm{Ti}$, $\mathrm{Cl}, \mathrm{Ca}, \mathrm{Ag}, \mathrm{Zn}$, and a fraction of $\mathrm{O}$ originate from exhaust particles. Calcium, phosphorus, sulfur, and zinc might derive from lubricant oil (Table S5), while Ti might originate from the wash coat of the catalytic converter. The weak N1s signal showed the typical energy of amino groups, confirming the presence of APAHs as observed from AMS chemical analysis (Table S4).

Figure $\mathrm{S} 10 \mathrm{~b}$ and $\mathrm{c}$ depict the deconvolution of $\mathrm{C} 1 \mathrm{~s}$ (panel b) and $\mathrm{O} 1 \mathrm{~s}$ spectra (panel c). In the $\mathrm{C} 1 \mathrm{~s}$ spectrum the carbon speciation can be derived in terms of graphitic $\mathrm{sp}^{2}$ carbon (at $284.5 \mathrm{eV}$ ), aliphatic $\mathrm{sp}^{3}$ carbon $(285.4 \mathrm{eV})$, and oxidized carbon in $\mathrm{C}-\mathrm{O}-\mathrm{C}$ bonds (ethers, alcohols; $286.4 \mathrm{eV}$ ), in $\mathrm{C}=\mathrm{O}$ bonds (carbonyls, quinones, $287.5 \mathrm{eV})$, and acidic $\mathrm{O}=\mathrm{C} *-\mathrm{OH}$ bonds $(288.9 \mathrm{eV})$ (EstradeSzwarckopf, 2004). The analysis revealed a soot sample dominated by $\mathrm{sp}^{2}$ hybridized carbon, the absence of the usual shakeup line associated with graphitic structures, and a significant "defect" contribution (at $283.5 \mathrm{eV}, 12 \%$ of the C1s signal) associated with carbon vacancies (Barinov et al., 2009), which indicates a significant concentration of carbon radical defects (Levi et al., 2015). All these elements hint to a structurally disordered soot surface, possibly having chemical toxicity or reactivity due to the presence of surface radicals. In addition, a rather high concentration of $\mathrm{sp}^{3}$ carbons (alkanes, $20 \%$ of the total carbon) was detected on the surface of the particles, in agreement with what was observed by AMS analysis (Fig. S6). From the O1s spectrum, the relative contributions of the $\mathrm{C}=\mathrm{O}$ carbonyl and carboxylic groups $(532.1 \mathrm{eV})$, the $\mathrm{C}-\mathrm{O}-\mathrm{C}$ group ethers and alcohols $(533.2 \mathrm{eV})$, and the $\mathrm{OH}$ group acids $(534.3 \mathrm{eV})$ were derived. A strong contribution of $\mathrm{Ti}-\mathrm{O} *$ in $\mathrm{TiO}_{2}$ was detected at $530.2 \mathrm{eV}$ coming from ashes. Oxidized calcium and silicon also contributed to the $\mathrm{O} 1 \mathrm{~s}$ spectrum as $\mathrm{Si}-\mathrm{O} *$ and $\mathrm{Ca}-\mathrm{O}$ * lines in the 533-535 eV range ( $\mathrm{Ni}$ and Ratner, 2008; Yang et al., 2011). Using the $\mathrm{C}=\mathrm{O}$ contribution at $532.2 \mathrm{eV}$ - the only line not overlapped by the $\mathrm{Si}, \mathrm{Ca}$, and Ti oxides - and the integrated intensity of the $\mathrm{C} 1 \mathrm{~s}$ line, we evaluated a soot surface oxidation by the ratio $\mathrm{O} /(\mathrm{O}+\mathrm{C})$, giving an oxidation rate of $10.8 \%$. This is in good agreement with Schuster et al. (2011), who found oxidation rates between $5.5 \%-11.5 \%$ for Euro 4-5 soot particles.

\subsection{Emission factors}

Figure 7 shows the emission factors (EFs) for BC, organics, PAHs, sulfate, ammonium, and nitrate for all the cars tested in this study. Table S6 summarizes these EFs in $\mu \mathrm{g} \mathrm{km}^{-1}$. Most of the particles were emitted during the cold-start cycles (both Artemis urban and WLTC) followed by motorway, hot WLTC, and hot urban cycles. GDI vehicles generally emitted considerably higher BC concentrations than PFI and diesel vehicles.

The average BC EFs for the GDI1, GDI3 (during Artemis cold urban cycle), and GDI2 (during WLTC cold) vehi- 


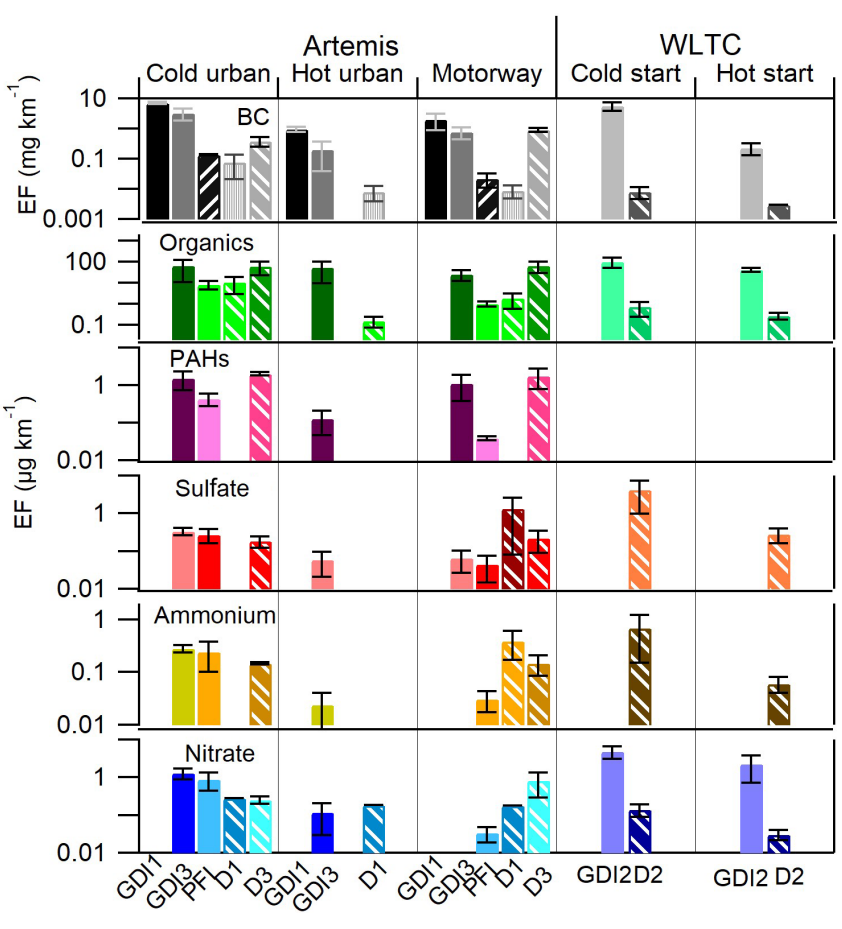

Figure 7. Emission factors for three diesel (D1, D2, and D3) and four gasoline (GDI1, GDI2, PFI, and GDI3) vehicles Euro 5: BC EFs are expressed in $\mathrm{mg} \mathrm{km}^{-1}$, while for organics, PAHs, sulfate, ammonium, and nitrate, the values are expressed in $\mu \mathrm{g} \mathrm{km}^{-1}$. Gasoline vehicles are shown with solid bars and diesel vehicles with pattern bars. The error bars correspond to $\pm 1 \sigma$ standard deviation.

cles were $7.14,3.18$, and $5.7 \mathrm{mg} \mathrm{km}^{-1}$ respectively, confirming a relatively small variability among the three vehicles equipped with the same injection system and posttreatment devices. These results are in a reasonably good agreement with previous studies, such as that of Saliba et al. (2017), who reported elemental carbon (EC) EFs between 0.08 and $5.8 \mathrm{mg} \mathrm{km}^{-1}$ for GDI light vehicles (models 20122014) during a unified cycle cold start. Taking into account the cycle distance, the fuel consumption, and the fuel density (Table S7), we converted BC EFs of GDI1, GDI3, and GDI2 to 120,51 , and $101 \mathrm{mg} \mathrm{kg}_{\text {fuel }}^{-1}$ respectively. These values are in good agreement with Pieber et al. (2018) and Platt et al. (2017), who reported for GDI Euro 5 light-duty vehicles EFs ranging from 10 and $100 \mathrm{mg} \mathrm{kg}_{\text {fuel }}^{-1}$ during coldstart WLTC and 10-250 $\mathrm{mg} \mathrm{kg}_{\text {fuel }}^{-1}$ during cold-start New European Driving Cycle (NEDC). BC EFs from PFI vehicles were considerably lower and lay in the range of 0.13 to $0.02 \mathrm{mg} \mathrm{km}^{-1}$ during urban cold-start and motorway cycles respectively. These values are in the same range of published work from Chan et al. (2014) and Short et al. (2015), who reported $\left(0.4-0.8 \mathrm{mg} \mathrm{km}^{-1}\right)$ for PFI vehicles. BC EF for the D1 vehicle during the Artemis cold-start cycle was $0.07 \mathrm{mg} \mathrm{km}^{-1}$ and for the D2 was $0.01 \mathrm{mg} \mathrm{km}^{-1}$ during a WLTC cold start in agreement with Platt et al. (2017).
The OA EFs emitted by the GDI3, GDI2, and PFI gasoline vehicles were $66.3,103.5$, and $8.4 \mu \mathrm{g} \mathrm{km}^{-1}$ (or 1.1, 2.2, and $0.2 \mathrm{mg} \mathrm{kg}_{\text {fuel }}^{-1}$ ) respectively during the cold-start cycle. These values are in agreement with Pieber et al. (2018), who reported EFs between 1 and $10 \mathrm{mg} \mathrm{kg}_{\text {fuel }}^{-1}$ for cold-start WLTC. The corresponding OA EFs of D2, D1, and D3 vehicles were $0.7,11$, and $61 \mu \mathrm{g} \mathrm{km}^{-1}$ (or $0.02,0.21$, and $0.94 \mathrm{mg} \mathrm{kg}_{\text {fuel }}^{-1}$ ) respectively. The high variability observed for diesel vehicles has been related to the performances of the after-treatment devices (mainly DOC and DPF). Platt et al. (2017) reported that the diesel vehicles equipped with DPF emitted very low amounts of OA (less than $0.01 \mathrm{~g} \mathrm{~km}_{\text {fuel }}^{-1}$ ), while OA EF of D3 is close to the values calculated for GDI vehicles, underlining how bad DPF conditions may affect PM emissions.

The PAH EFs were measured only for GDI3, PFI, and D3 vehicles. EFs for GDI3 were 1.5 and $1.1 \mu \mathrm{g} \mathrm{km}^{-1}$ during cold urban and motorway cycles respectively. These results are in excellent agreement with EFs of $1.6-1.9 \mu \mathrm{g} \mathrm{km}{ }^{-1}$ recently published for two GDI cars (Yang et al., 2018). The PFI vehicle emitted considerably lower PAHs, only $0.4 \mu \mathrm{g} \mathrm{km}^{-1}$ for cold urban and $0.04 \mu \mathrm{g} \mathrm{km}^{-1}$ for motorway cycles. These values are in relatively good agreement with Cheung et al. (2010), who reported an EF of $0.67 \mu \mathrm{g} \mathrm{km}^{-1}$ from a PFI gasoline vehicle. The D3 vehicle PAH EFs were $2.0 \mu \mathrm{g} \mathrm{km}^{-1}$ during the cold urban cycle and $1.7 \mu \mathrm{g} \mathrm{km}^{-1}$ during the motorway cycle. These findings are in good agreement with Alves et al. (2015), who reported EFs of 2.3 and $0.6 \mu \mathrm{gm}^{-1}$ for cold urban and motorway cycles of a diesel Euro 5 vehicle. When Cheung et al. (2010) added a DPF to a Euro 4 diesel vehicle (converting it into a "Euro 5") the PAHs were below the detection limit. Reports from literature emphasize the high variability of PAH emissions from different diesel Euro 5 cars. As already mentioned in the previous sections both OA and PAH EFs for D3 were surprisingly high for a diesel vehicle equipped with a DPF, suggesting a failure in the after-treatment device, as also supported by TEM images in Fig. 6.

Sulfate, ammonium, and nitrate EFs were generally low. The highest sulfate EFs were observed for the D2 during the cold-start WLTC cycle with an EF of $4.2 \mu \mathrm{g} \mathrm{km}^{-1}$ and for the D1 during the Artemis motorway cycle with values of $1.3 \mu \mathrm{g} \mathrm{km}^{-1}$. Both D1 and D2 cars were equipped with a CDPF, while the D3 was equipped with an FBC-DPF and had lower sulfate EFs $\left(0.18-0.22 \mu \mathrm{g} \mathrm{km}^{-1}\right)$, underlying the determining influence of the DPF technology on PM chemical composition. Nitrate was mostly emitted by gasoline cars. The highest EFs were measured for the GDI2 vehicle with 2.2 and $4.9 \mu \mathrm{g} \mathrm{km}^{-1}$ for cold- and hot-start WLTC respectively.

\section{Conclusions}

We characterized the chemical composition of three diesel (two CDPF and one FBC-DPF) and four gasoline (three GDI 
and one PFI equipped with TWC) Euro 5 light-duty vehicles during transient cycles, and we evaluated their emission factors. Most of the particulate matter was emitted at the beginning of the cold-start cycle due to the incomplete combustion and low catalyst efficiency. BC was always the dominant species, accounting for $83 \%-98 \%$ of the total particle mass concentration, while the corresponding $\mathrm{OA}$ fraction ranged between $1.8 \%$ and $14 \%$.

The $\mathrm{BC}, \mathrm{OA}$, and PAH emissions of the GDI gasoline vehicles were 4-50 times higher compared to the gasoline PFI vehicle emissions. In total 45 PAHs were identified. Approximately $52 \%-66 \%$ of the PAHs were unsubstituted PAHs, followed by methylated PAHs $(14 \%-21 \%$ of the PAHs), oxygenated PAHs (5\%-19\%), NPAHs (1\%-11\%), and amino PAHs ( $1 \%-6 \%)$. Unexpectedly, the GDI vehicle emitted the highest concentrations of nitro-PAHs, questioning the validity of using some NPAHs as a marker of diesel emissions.

Oil droplets containing metallic components such as calcium, phosphorus, sulfur, and zinc were observed in PM from both gasoline and diesel vehicles. Organosulfur-containing ion fragments were detected for the first time on particles emitted from gasoline vehicles, probably from the release of lubricant oil, and accounted for $2 \%-7 \%$ of the total organic mass concentration. Analysis of particles emitted from the PFI vehicle revealed a highly disordered soot surface, which could affect both chemical reactivity and PM toxicity.

Nanoparticles of $15 \mathrm{~nm}$ diameter, mainly composed of ammonium bisulfate, were measured during the motorway cycle, suggesting passive regeneration of the DPF for CDPF diesel vehicles. This behaviour was not observed for the FBC-DPF vehicle, indicating that the different aftertreatment strategy highly affects the PM size and composition.

Diesel cars equipped with well-functioning after-treatment devices generally emitted far less pollutants than the gasoline vehicles, but in the case of a DPF failure, very high levels of PM, similar to those reported for the GDI vehicles, were measured. This indicates that the DPF condition is important and attention should be given to its maintenance during the lifetime of the vehicle.

All the particle characteristics investigated in this work should be considered in emission control strategies and in the assessment of the impact of light-duty particle emissions on the environment and on human health.

Data availability. All data from this study are available from the authors upon request.

Supplement. The supplement related to this article is available online at: https://doi.org/10.5194/acp-21-4779-2021-supplement.
Author contributions. BD'A, MA, and EK designed the research. EK performed and analysed the measurements of the D3, PFI, and GDI3 cars. AMV performed and analysed the measurements of the D2 and GDI2 cars. BR'M performed and analysed the measurements of the D1 and GDI1 cars. BM, BTR, YL, CLo, and BV contributed to the experimental set-up and the experimental procedure. YL, CLo, and BV drove the cars. DF, CLa, and PP performed the TEM and XPS analysis. EK synthesized all the data and wrote the paper with contributions from BD'A, DF, and PP. AD performed the GC-MS analysis for the PAHs.

Competing interests. The authors declare that they have no conflict of interest.

Acknowledgements. The authors would like to thank Antoinette Boreave and Laurence Buriel from IRCELYON and Patrick Tassel from IFSTTAR for their helpful support.

The authors would like to thank the GDR SUIE (GDR CNRS 3622) for the financial support to make complementary investigations on TEM and XPS analysis at the CINaM laboratory.

Financial support. This research has been supported by the ADEME CORTEA programme with the project CAPVEREA (contract no. 1466C0001) and the project MAESTRO (contract no. $1766 \mathrm{C} 0001)$

Review statement. This paper was edited by John Liggio and reviewed by two anonymous referees.

\section{References}

ACEA: European Automobile Manufacturers Association, Pocket Guide 2020-2021, available at: https://www.acea.be/uploads/ publications/ACEA_Pocket_Guide_2020-2021.pdf (last access: 12 March 2021), 2020.

Aiken, A. C., DeCarlo, P. F., and Jimenez, J. L.: Elemental analysis of organic species with electron ionization high-resolution mass spectrometry, Anal. Chem., 79, 8350-8358, 2007.

Aiken, A. C., Salcedo, D., Cubison, M. J., Huffman, J. A., DeCarlo, P. F., Ulbrich, I. M., Docherty, K. S., Sueper, D., Kimmel, J R., Worsnop, D. R., Trimborn, A., Northway, M., Stone, E. A., Schauer, J. J., Volkamer, R. M., Fortner, E., de Foy, B., Wang, J., Laskin, A., Shutthanandan, V., Zheng, J., Zhang, R., Gaffney, J., Marley, N. A., Paredes-Miranda, G., Arnott, W. P., Molina, L. T., Sosa, G., and Jimenez, J. L.: Mexico City aerosol analysis during MILAGRO using high resolution aerosol mass spectrometry at the urban supersite (T0) - Part 1: Fine particle composition and organic source apportionment, Atmos. Chem. Phys., 9, 6633-6653, https://doi.org/10.5194/acp-9-6633-2009, 2009.

Alfarra, M. R.: Insights into atmospheric organic aerosols using an aerosol mass spectrometer, in: Department of Chemical Engineering, UMIST, Manchester, UK, 2004. 
Alkidas, A. C.: Combustion advancements in gasoline engines, Energy Convers. Manag., 48, 2751-2761, 2007.

Alkourdi, F., Karabet, F., and Dimashki, M.: Characterization, concentrations and emission rates of polycyclic aromatic hydrocarbons in the exhaust emissions from in-service vehicles in Damascus, Atmos. Res., 120-121, 68-77, 2013.

Alves, C. A., Barbosa, C., Rocha, S., Calvo, A., Nunes, T., Cerqueira, M., Pio, C., Karanasiou, A., and Querol, X.: Elements and polycyclic aromatic hydrocarbons in exhaust particles emitted by light-duty vehicles, Environ. Sci. Pollut. Res., 22, 1152611542, 2015.

Andersson, J., May, J., Favre, C., Bosteels, D., de Vries, S., Heaney, M., Keenan, M., and Mansell, J.: On-road and chassis dynamometer evaluations of emissions from two Euro 6 diesel vehicles, SAE Int. J. Fuels Lubr., 7, 919-934, https://doi.org/10.4271/2014-01-2826, 2014.

André, M.: The ARTEMIS European driving cycles for measuring car pollutant emissions, Sci. Total Environ., 334-335, 73-84, 2004.

Argyropoulos, G., Samara, C., Voutsa, D., Kouras, A., Manoli, E., Voliotis, A., Tsakis, A., Chasapidis, L., Konstandopoulos, A., and Eleftheriadis, K.: Concentration levels and source apportionment of ultrafine particles in road microenvironments, Environ. Sci. Tech., 129, 68-78, 2016.

Arnold, F., Pirjola, L., Rönkkö, T., Reichl, U., Schlager, H., Lähde, T., Heikkil, J., and Keskinen, J.: First online measurements of sulfuric acid gas in modern heavy-duty diesel engine exhaust: implications for nanoparticle formation, Environ. Sci. Tech., 46, 11227-11234, 2012.

Bandowe, B. A. M. and Meusel, H.: Nitrated polycyclic aromatic hydrocarbons (nitro-PAHs) in the environment - A review, Sci. Total Environ., 581-582, 237-257, 2017.

Barinov, A., Malcioglu, O. B., Fabris, S., Sun, T., Gregoratti, L., Dalmiglio, M., and Kiskinova, M.: Initial stages of oxidation on graphitic surfaces: Photoemission study and density functional theory calculations, J. Phys. Chem. C, 113, 9009-9013, 2009.

Barone, T. L., Storey, J. M. E., Youngquist, A. D., and Szybist, J. P.: An analysis of direct-injection spark-ignition (DISI) soot morphology, Atmos. Environ., 49, 268-274, 2012.

Bergmann, M., Kirchner, U., Vogt, R., and Benter, T.: On-road and laboratory investigation of low-level PM emissions of a modern diesel particulate filter equipped diesel passenger car, Atmos. Environ., 43, 1908-1916, 2009.

Bikas, G. and Zervas, E.: Regulated and Non-Regulated Pollutants Emitted during the Regeneration of a Diesel Particulate Filter, Energ. Fuels, 21, 1543-1547, 2007.

Borbon, A., Gilman, J. B., Kuster, W. C., Grand, N., Chevaillier, S., Colomb, A., Dolgorouky, C., Gros, V., Lopez, M., Sarda-Esteve, R., Holloway, J., Stutz, J., Petetin, H., McKeen, S., Beekmann, M., Warneke, C., Parrish, D. D., and de Gouw, J. A.: Emission ratios of anthropogenic volatile organic compounds in northern mid-latitude megacities: Observations versus emission inventories in Los Angeles and Paris, J. Geophys. Res.-Atmos., 118, 2041-2057, 2013.

Bruns, E. A., El Haddad, I., Keller, A., Klein, F., Kumar, N. K., Pieber, S. M., Corbin, J. C., Slowik, J. G., Brune, W. H., Baltensperger, U., and Prévôt, A. S. H.: Inter-comparison of laboratory smog chamber and flow reactor systems on organic aerosol yield and composition, Atmos. Meas. Tech., 8, 23152332, https://doi.org/10.5194/amt-8-2315-2015, 2015.

Cadrazco, M., Santamaría, A., and Aguledo, J. R.: Chemical and nanostructural characteristics of the particulate matter produced by renewable diesel fuel in an automotive diesel engine, Combust. Flame, 203, 130-142, 2019.

Canagaratna, M. R., Jayne, J. T., Ghertner, D. A., Herndon, S., Shi, Q., Jimenez, J. L., Silva, P. J., Williams, P., Lanni, T., Drewnick, F., Demerjian, K. L., Kolb, C. E., and Worsnop, D. R.: Chase Studies of Particulate Emissions from in-use New York City Vehicles, Aerosol Sci. Technol., 38, 555-573, 2004.

Cassee, F. R., Heroux, M. E., Gerlofs-Nijland, M. E., and Kelly, F. J.: Particulate matter beyond mass: recent health evidence on the role of fractions, chemical constituents and sources of emission, Inhal. Toxicol., 25, 802-812, 2013.

Chan, T. W., Meloche, E., Kubsh, J., and Brezny, R.: Black carbon emissions in gasoline exhaust and a reduction alternative with a gasoline particulate filter, Environ. Sci. Technol., 48, 6027-6034, 2014.

Chen, L., Liang, Z., Zhang, X., and Shuai, S.: Characterizing particulate matter emissions from GDI and PFI vehicles under transient and cold start conditions, Fuel, 189, 131-140, 2017.

Chen, R., Hu. B., Liu, Y., Xu, J. X., Yang, G. S., Xu, D. D., and Chen, C. Y.: Beyond $\mathrm{PM}_{2.5}$ : The role of ultrafine particles on adverse health effects of air pollution, Biochim. Biophys. Acta., 1860, 2844-2855, 2016.

Cheung, K., Ntziachristos, L., Tzamkiozis, T., Schauer, J., Samaras, Z., Moore, K., and Sioutas, C.: Emissions of particulate trace elements, metals and organic species from gasoline, diesel, and biodiesel passenger vehicles and their relation to oxidative potential, Aerosol Sci. Technol., 44, 500-513, 2010.

Chikhi, S., Boughedaoui, M., Kerbachi, R., and Joumard, R.: Onboard measurement of emissions from liquefied petroleum gas, gasoline and diesel powered passenger cars in Algeria, J. Environ. Sci., 26, 1651-1659, 2014.

Chirico, R., Prévôt, A. S. H., DeCarlo, P. F., Heringa, M. F., Richter, R., Weingartner, E., and Baltensperger, U.: Aerosol and trace gas vehicle emission factors measured in a tunnel using an Aerosol Mass Spectrometer and other online instrumentation, Atmos. Environ., 45, 2182-2192, 2011.

Clairotte, M., Adam, T. W., Zardini, A. A., Manfredi, U., Martini, G., Krasenbrink, A., Vicet, A., Tournié, E., and Astorga, C.: Effects of low temperature on the cold start gaseous emissions from light duty vehicles fueled by ethanol-blended gasoline, Appl. Energ., 102, 44-54, 2013.

Collier, S., Zhou, S., Kuwayama, T., Forestieri, S., Brady, J., Zhang, M., Kleeman, M., Cappa, C., Bertram, T., and Zhang, Q.: Organic $\mathrm{PM}$ emissions from vehicles: composition, $\mathrm{O} / \mathrm{C}$ ratio, and dependence on PM concentration, Aerosol Sci. Technol., 49, 8697, 2015.

Dallmann, T. R. and Harley, R. A.: Evaluation of mobile source emission trends in the United States, J. Geophys. Res., 115, D14305, https://doi.org/10.1029/2010JD013862, 2010.

Dallmann, T. R., Onasch, T. B., Kirchstetter, T. W., Worton, D. R., Fortner, E. C., Herndon, S. C., Wood, E. C., Franklin, J. P., Worsnop, D. R., Goldstein, A. H., and Harley, R. A.: Characterization of particulate matter emissions from on-road gasoline and diesel vehicles using a soot particle 
aerosol mass spectrometer, Atmos. Chem. Phys., 14, 7585-7599, https://doi.org/10.5194/acp-14-7585-2014, 2014.

de Abrantes, R., Assunção, J. V., and Pesquero, C. R.: Emission of polycyclic aromatic hydrocarbons from light-duty diesel vehicles exhaust, Atmos. Environ., 38, 1631-1640, 2004.

DeCarlo, P. F., Kimmel, J. R., Trimborn, A., Northway, M. J., Jayne, J. T., Aiken, A. C., Gonin, M., Fuhrer, K., Horvath, T., Docherty, K., Worsnop, D. R., and Jimenez, J. L.: Fielddeployable, high-resolution, time-of-flight aerosol mass spectrometer, Anal. Chem., 78, 8281-8289, 2006.

de Souza, C. V. and Corrêa, S. M.: Polycyclic aromatic hydrocarbons in diesel emission, diesel fuel and lubricant oil, Fuel, 185, 925-931, 2016.

di Rattalma, M. F. and Perotti, G.: The dieselgate: a legal perspective, Springer, Cham, https://doi.org/10.1007/978-3-319-483238, 179-218, 2017.

Drewnick, F., Hings, S. S., DeCarlo, P. F., Jayne, J. T., Gonin, M., Fuhrer, K., Weimer, S., Jimenez, J. L., Demerjian, K. L., Borrmann, S., and Worsnop, D. R.: A new time-of-flight aerosol mass spectrometer (ToF-AMS) - instrument description and first field deployment, Aerosol Sci. Technol., 39, 637-658, 2005.

Du, Z., Hu, M., Peng, J., Zhang, W., Zheng, J., Gu, F., Qin, Y., Yang, Y., Li, M., Wu, Y., Shao, M., and Shuai, S.: Comparison of primary aerosol emission and secondary aerosol formation from gasoline direct injection and port fuel injection vehicles, Atmos. Chem. Phys., 18, 9011-9023, https://doi.org/10.5194/acp18-9011-2018, 2018.

Durant, J. L., Busby, W. F., Lafleur, A. L., Penman, B. W., and Crespi, C. L.: Human cell mutagenicity of oxygenated, nitrated and unsubstituted polycyclic aromatic hydrocarbons associated with urban aerosols, Mutat. Res.-Genet. Tox., 371, 123-157, 1996.

Dzepina, K., Arey, J., Marr, L. C., Worsnop, D. R., Salcedo, D., Zhang, Q., Onasch, T. B., Molina, L. T., Molina, M. J., and Jimenez, J. L.: Detection of particle-phase polycyclic aromatic hydrocarbons in Mexico City using an aerosol mass spectrometer, Int. J. Mass Spectrom., 263, 152-170, 2007.

El Haddad, I.: Primary and secondary fractions of the organic aerosol: Methodologies and application to a Mediterranean urban environment, Marseille, PhD Thesis, Aix-Marseille University, Marseille, France, 2011.

El Haddad, I., Marchand, N., Wortham, H., Piot, C., Besombes, J.L., Cozic, J., Chauvel, C., Armengaud, A., Robin, D., and Jaffrezo, J.-L.: Primary sources of $\mathrm{PM}_{2.5}$ organic aerosol in an industrial Mediterranean city, Marseille, Atmos. Chem. Phys., 11, 2039-2058, https://doi.org/10.5194/acp-11-2039-2011, 2011.

Eriksson, A. C., Nordin, E. Z., Nystrom, R., Pettersson, E., Swietlicki, E., Bergvall, C., Westerholm, R., Boman, C., and Pagels, J. H.: Particulate PAH emissions from residential biomass combustion: time-resolved analysis with aerosol mass spectrometry, Environ. Sci. Technol., 48, 7143-7150, 2014.

Estrade-Szwarckopf, H.: XPS photoemission in carbonaceous materials: A "defect" peak beside the graphitic asymmetric peak, Carbon 42, 1713-1721, 2014.

Fu, H., Wang, Y., Li, X., and Shuai, S.: Impacts of cold-start and gasoline RON on particulate emission from vehicles powered by GDI and PFI engines, SAE Int. Pow. Fuels \& Lubr., United States, https://doi.org/10.4271/2014-01-2836, 2014.
Gaddam, C. K. and Vander Wal, R. L.: Physical and chemical characterization of SIDI engine particulates, Comb. Flame, 160, 2517-2528, 2013.

Gentner, D. R., Jathar, S. H., Gordon, T. D., Bahreini, R., Day, D. A., El Haddad, I., Hayes, P. L., Pieber, S. M., Platt, S. M., de Gouw, J., Goldstein, A. H., Harley, R. A., Jimenez, J. L., Prévôt, A. S., and Robinson, A. L.: Review of Urban Secondary Organic Aerosol Formation from Gasoline and Diesel Motor Vehicle Emissions, Environ. Sci. Technol., 51, 1074-1093, 2017.

Gordon, T. D., Tkacik, D. S., Presto, A. A., Zhang, M., Jathar, S., Nguyen, N., Massetti, J., Truong, T., Cicero-Fernandez, P., Maddox, C., Rieger, P., Chattopadhyay, S., Maldonado, H., Maricq, M., M., and Robinson, A. L.: Primary gas-and particle phase emissions and secondary organic aerosol production from gasoline and diesel off-road engines, Environ. Sci. Technol., 47, 14137-14146, 2013.

Grieshop, A. P., Lipsky, E. M., Pekney, N. J., Takahama, S., and Robinson, A. L.: Fine particle emission factors from vehicles in a highway tunnel: Effects of fleet composition and season, Atmos. Environ., 40, S287-S298, 2006.

Hartikainen, A., Tiitta, P., Ihalainen, M., Yli-Pirilä, P., Orasche, J., Czech, H., Kortelainen, M., Lamberg, H., Suhonen, H., Koponen, H., Hao, L., Zimmermann, R., Jokiniemi, J., Tissari, J., and Sippula, O.: Photochemical transformation of residential wood combustion emissions: dependence of organic aerosol composition on $\mathrm{OH}$ exposure, Atmos. Chem. Phys., 20, 6357-6378, https://doi.org/10.5194/acp-20-6357-2020, 2020.

Heeb, N. V., Forss, J. A.-M., Brühlmann, S., Lüscher, R., Saxer, C. J., and Hug, P.: Three-way catalyst-induced formation of ammonia-velocity- and acceleration-dependent emission factors, Atmos. Environ., 40, 5986-5997, 2006.

Herring, C. H., Faiola, C. L., Massoli, P., Sueper, D., Erickson, M. H., McDonald, J. D., Simpson, C. D., Yost, M. G., Jobson B. T., and VanReken, M. T.: New methodology for quantifying polycyclic aromatic hydrocarbons (PAHs) using high- resolution aerosol mass spectrometry, Aerosol Sci. Technol., 49, 11311148, 2015.

Hime, N. J., Marks, G. B., and Cowie, C. T.: A comparison of the health effects of ambient particulate matter air pollution from five emission sources, Int. J. Env. Res. Pub. He., 15, E1206, https://doi.org/10.3390/ijerph15061206, 2018.

Hoffman, J., Staelens, J., Cordell, R., Stroobants, C., Zikova, N., Hama, S. M. L., Wyche, K. P., Kos, G. P. A., Van Der Zee, S., Smallbone, K. L., Weijers, E. P. Monks, P. S., and Roekens, E.: Ultrafine particles in four European urban environments: Results from a new continuous long-term monitoring network, Atmos. Environ., 136, 68-81, 2016.

Huang, L., Bohac, S. V., Chernyak, S. M., and Batterman, S. A.: Composition and integrity of PAHs, nitro-PAHs, hopanes, and steranes in diesel exhaust particulate matter, Water Air Soil Pollut., 224, 1630, https://doi.org/10.1007/s11270-013-1630-1, 2012.

Hudda, N., Fruin, S., Delfino, R. J., and Sioutas, C.: Efficient determination of vehicle emission factors by fuel use category using on-road measurements: downward trends on Los Angeles freight corridor I-710, Atmos. Chem. Phys., 13, 347-357, https://doi.org/10.5194/acp-13-347-2013, 2013. 
Huo, H., Yao, Z., Zhang, Y., Shen, X., Zhang, Q., and He, K.: Onboard measurements of emissions from diesel trucks in five cities in China, Atmos. Environ., 54, 159-167, 2012.

Hyvärinen, A.-P., Vakkari, V., Laakso, L., Hooda, R. K., Sharma, V. P., Panwar, T. S., Beukes, J. P., van Zyl, P. G., Josipovic, M., Garland, R. M., Andreae, M. O., Pöschl, U., and Petzold, A.: Correction for a measurement artifact of the MultiAngle Absorption Photometer (MAAP) at high black carbon mass concentration levels, Atmos. Meas. Tech., 6, 81-90, https://doi.org/10.5194/amt-6-81-2013, 2013.

IARC: International Agency for Research on Cancer, Monographs on the Evaluation of Carcinogenic Risk of Chemicals to Humans, Vol. 92, Some Non-heterocyclic Polycyclic Aromatic Hydrocarbons and Some Related Exposures, IARC, Lyon, France, 2010.

IARC: A Review of human carcinogens: some chemicals in industrial and consumer products, food and drinking-water, IARC Monographs on the Evaluation of Carcinogenic Risks to $\mathrm{Hu}-$ mans, Vol. 101, IARC, Lyon, France, 2013.

IARC: Diesel and Gasoline Engine Exhausts and Some Nitroarenes, IARC Monographs on the Evaluation of Carcinogenic Risks to Humans, Vol. 105, Lyon, France, 2014.

Isaacman, G., Chan, A. W. H., Nah, T., Worton, D. R., Ruehl, C. R., Wilson, K. R., and Goldstein, A. H.: Heterogeneous $\mathrm{OH}$ Oxidation of Motor Oil Particles Causes Selective Depletion of Branched and Less Cyclic Hydrocarbons, Environ. Sci. Technol., 46, 10632-10640, 2012.

Jaworski, A., Kuszewski, H., Ustrzycki, A., Balawender, K., Lejda, K., and Woś, P.: Analysis of the repeatability of the exhaust pollutants emission research results for cold and hot starts under controlled driving cycle conditions, Environ. Sci. Pollut. Res., 25, 17862-17877, 2018.

Jimenez, J. L., McManus, J. B., Shorter, J. H., Nelson, D. D., Zahniser, M. S., Koplow, M., McRae, G. J., and Kolb C. E.: Cross road and mobile tunable infrared laser measurements of nitrous oxide emissions from motor vehicles, Chemos., Glob. Change Sci., 2, 397-412, 2000.

Kaltsonoudis, C., Kostenidou, E., Louvaris, E., Psichoudaki, M., Tsiligiannis, E., Florou, K., Liangou, A., and Pandis, S. N.: Characterization of fresh and aged organic aerosol emissions from meat charbroiling, Atmos. Chem. Phys., 17, 7143-7155, https://doi.org/10.5194/acp-17-7143-2017, 2017.

Karavalakis, G., Boutsika V., Stournas, S., and Bakeas, E.: Biodiesel emissions profile in modern diesel vehicles. Part 2: Effect of biodiesel origin on carbonyl, PAH, nitro-PAH and oxy-PAH emissions, Sci. Total Environ., 409, 738-747, 2011.

Karjalainen, P., Pirjola, L., Heikkilä, J., Lähde, T., Tzamkiozis, T., Ntziachristos, L., Keskinen, J., and Rönkkö, T.: Exhaust particles of modern gasoline vehicles: a laboratory and an on-road study, Atmos. Environ., 97, 262-270, 2014.

Karjalainen, P., Timonen, H., Saukko, E., Kuuluvainen, H., Saarikoski, S., Aakko-Saksa, P., Murtonen, T., Bloss, M., Dal Maso, M., Simonen, P., Ahlberg, E., Svenningsson, B., Brune, W. H., Hillamo, R., Keskinen, J., and Rönkkö, T.: Time-resolved characterization of primary particle emissions and secondary particle formation from a modern gasoline passenger car, Atmos. Chem. Phys., 16, 8559-8570, https://doi.org/10.5194/acp16-8559-2016, 2016.

Keyte, I. J., Albinet, A., and Harrison R. M.: On-road traffic emissions of polycyclic aromatic hydrocarbons and their oxy- and nitro- derivative compounds measured in road tunnel environments, Sci. Total Environ., 566-567, 1131-1142, 2016.

Korhonen P., Kulmala M., Laaksonen A., Viisanen Y., McGraw R., and Seinfeld J.H., Ternary nucleation of $\mathrm{H}_{2} \mathrm{SO}_{4}, \mathrm{NH}_{3}$ and $\mathrm{H}_{2} \mathrm{O}$ in the atmosphere, J. Geophys. Res., 104, 26349-26353, 1999.

Kostenidou, E., Lee, B. H., Engelhart, G. J., Pierce, J. R., and Pandis, S. N.: Mass spectra deconvolution of low, medium and high volatility biogenic secondary organic aerosol, Environ. Sci. Technol., 43, 4884-4889, 2009.

Kostenidou, E., Florou, K., Kaltsonoudis, C., Tsiflikiotou, M., Vratolis, S., Eleftheriadis, K., and Pandis, S. N.: Sources and chemical characterization of organic aerosol during the summer in the eastern Mediterranean, Atmos. Chem. Phys., 15, 11355-11371, https://doi.org/10.5194/acp-15-11355-2015, 2015.

Kürten, A.: New particle formation from sulfuric acid and ammonia: nucleation and growth model based on thermodynamics derived from CLOUD measurements for a wide range of conditions, Atmos. Chem. Phys., 19, 5033-5050, https://doi.org/10.5194/acp-19-5033-2019, 2019.

Lamma, L.: Mise au point d'une méthode de mesure des siloxanes méthyliques volatils dans le biogaz et dans l'air ambiant et étude de leur impact sur les systèmes photocatalytiques, PhD Thesis, Univ. Lyon, France, 2017.

Lapuerta, M., Rodríguez-Fernández, J., and Sánchez-Valdepeñas, J.: Soot reactivity analysis and its implications on diesel filter regeneration, Prog. Energy Combust. Sci., 78, 100833, https://doi.org/10.1016/j.pecs.2020.100833, 2020.

Lawrence, S., Sokhi, R., Ravindra, K., Mao, H., Prain, H. D., and Bull, I. D.: Source apportionment of traffic emissions of particulate matter using tunnel measurements, Atmos. Environ., 77, 548-557, 2013.

Lea-Langton, A., Li, H., and Andrews, G.: Comparison of particulate PAH emissions for diesel, biodiesel and cooking oil using a heavy duty DI diesel engine, SAE Int. Pow. Fuels \& Lubr., United States, https://doi.org/10.4271/2008-01-1811, 2008.

Lelieveld, J., Klingmüllera, K., Pozzer, A., Burnett, R. T., Haines A., and Ramanathan, V.: Effects of fossil fuel and total anthropogenic emission removal on public health and climate, P. Natl. Acad. Sci. USA, 116, 7192-7197, 2019.

Levi, G., Senneca, O., Causà, M., Salatino, P., Lacovig, P., and Lizzit, S.: Probing the chemical nature of surface oxides during coal char oxidation by high-resolution XPS, Carbon, 90, 181196, 2015.

Liang, B., Ge, Y., Tan, J., Han, X., Gao, L., Hao, L., Ye, W., and Dai, P.: Comparison of PM emissions from a gasoline direct injected (GDI) vehicle and a port fuel injected (PFI) vehicle measured by electrical low pressure impactor (ELPI) with two fuels: gasoline and M15 methanol gasoline, J. Aerosol Sci., 57, 22-31, 2013.

Liati, A., Schreiber, D., Arroyo Rojas Dasilva, Y., and Dimopoulos Eggenschwiler, P.: Ultrafine particle emissions from modern Gasoline and Diesel vehicles: An electron microscopic perspective, Environ. Pollut. 239, 661-669, 2018.

Louis, C., Liu, Y., Tassel, P., Perret, P., Chaumond, A. and André, M.: PAH, BTEX carbonyl compound, black-carbon, $\mathrm{NO}_{2}$ and ultrafine particle dynamometer bench emissions for Euro 4 and Euro 5 diesel and gasoline passenger cars, Atmos. Environ., 141, 80-95, 2016.

Majewski, W. A. and Khair, M. K.: Diesel emissions and their control, SAE Technical Paper, SAE, Warrendale, PA, USA, 2006. 
Maricq, M. M.: Chemical characterization of particulate emissions from diesel engines: A review, J. Aerosol Sci., 38, 1079-1118, 2007.

Marques, B., Kostenidou, E., Temime-Roussel, B., Ferronato C., Martinez-Valiente, A., Michel, A., Liu, Y., Vansevenant, B., Fine L., Ferronato, C., and D'Anna B.: Chemical characterization of fresh volatile organic compound emissions from diesel and gasoline EURO 5 light vehicles, in preparation, 2021.

Marr, L., Kirchstetter, T., Harley, R., Miguel, A., Hering, S., and Hammond, S.: Characterization of polycyclic aromatic hydrocarbons in motor vehicle fuels and exhaust emissions, Environ. Sci. Technol., 33, 3091-3099, 1999.

Mathis, U., Kaegi, R., Mohr, M., and Zenobi, R.: TEM analysis of volatile nanoparticles from particle trap equipped diesel and direct-injection spark-ignition vehicles, Atmos. Environ., 38, 4347-4355, 2004.

McLafferty, F. W. and Turecek, F.: Interpretation of Mass Spectra, University Science Books, Mill Valley, CA, USA, 1993.

Mills, N. L., Miller, M. R., Lucking, A. J., Beveridge, J., Flint, L., Boere, A. J., Fokkens, P. H., Boon, N. A., Sandstrom, T., Blomberg, A., Duffin, R., Donaldson, K., Hadoke, P. W. F., Cassee, F. R., and Newby, D. E.: Combustion-derived nanoparticulate induces the adverse vascular effects of diesel exhaust inhalation, Eur. Heart J., 32, 2660-2671, 2011.

Mohr, C., Huffman, J. A., Cubison, M. J., Aiken, A. C., Docherty, K. S., Kimmel, J. R., Ulbrich, I. M., Hannigan, M., and Jimenez, J. L.: Characterization of primary organic aerosol emissions from meat cooking, trash burning, and motor vehicles with highresolution aerosol mass spectrometry and comparison with ambient and chamber observations, Environ. Sci. Technol., 43, 24432449, 2009.

Mohr, C., DeCarlo, P. F., Heringa, M. F., Chirico, R., Slowik, J. G., Richter, R., Reche, C., Alastuey, A., Querol, X., Seco, R., Peñuelas, J., Jiménez, J. L., Crippa, M., Zimmermann, R., Baltensperger, U., and Prévôt, A. S. H.: Identification and quantification of organic aerosol from cooking and other sources in Barcelona using aerosol mass spectrometer data, Atmos. Chem. Phys., 12, 1649-1665, https://doi.org/10.5194/acp-121649-2012, 2012.

Morawska, L., Ristovski, Z. D., Johnson, G. R., Jayaratne, E. R., and Mengersen, K.: Novel method for on-road emission factor measurements using a plume capture trailer, Environ. Sci. Technol., 41, 574-579, 2007.

Muñoz, M., Haag, R., Honegger, P., Zeyer, K., Mohn, J., Comte, P., Czerwinski, J., Heeb, N. V.: Co-formation and co-release of genotoxic PAHs, alkyl-PAHs and soot nanoparticles from gasoline direct injection vehicles, Atmos. Environ., 178, 242-254, 2018.

Myung, C. L., Choi, K., Kim, J., Lim, Y., Lee, J., and Park, S.: Comparative study of regulated and unregulated toxic emissions characteristics from a spark Ignition direct injection light-duty vehicle fueled with gasoline and liquid phase LPG (Liquefied Petroleum Gas), Energy, 44, 189-196, 2012.

Ni, M. and Ratner, B. D.: Differentiating calcium carbonate polymorphs by surface analysis techniques - An XPS and TOF-SIMS study, Surf. Interface Anal., 40, 1356-1361, 2008.

Ntziachristos, L., Samaras, Z., Zervas, E., and DorlheÌne, P.: Effects of a catalysed and an additized particle filter on the emissions of a diesel passenger car operating on low sulphur fuels, Atmos. Environ., 39, 4925-4936, 2005.

Ortega, I. K., Kurtén, T., Vehkamäki, H., and Kulmala, M.: The role of ammonia in sulfuric acid ion induced nucleation, Atmos. Chem. Phys., 8, 2859-2867, https://doi.org/10.5194/acp-8-28592008, 2008.

Peitzmeier, C., Loschke, C., Wiedenhaus, H., and Klemm, O.: Real-world vehicle emissions as measured by in situ analysis of exhaust plumes, Environ. Sci. Pollut. Res., 24, 23279-23289, https://doi.org/10.1007/s11356-017-9941-1, 2017.

Pieber, S. M., Kumar, N. K., Klein, F., Comte, P., Bhattu, D., Dommen, J., Bruns, E. A., Kılıç, D., El Haddad, I., Keller, A., Czerwinski, J., Heeb, N., Baltensperger, U., Slowik, J. G., and Prévôt, A. S. H.: Gas-phase composition and secondary organic aerosol formation from standard and particle filterretrofitted gasoline direct injection vehicles investigated in a batch and flow reactor, Atmos. Chem. Phys., 18, 9929-9954, https://doi.org/10.5194/acp-18-9929-2018, 2018.

Pikridas, M., Riipinen, I., Hildebrandt, L., Kostenidou, E., Manninen, H., Mihalopoulos, N., Kalivitis, N., Burkhart, J. F., Stohl, A., Kulmala, M., and Pandis, S. N.: New particle formation at a remote site in the eastern Mediterranean, J. Geophys. Res., 117, D12205, https://doi.org/10.1029/2012JD017570, 2012.

Platt, S. M., El Haddad, I., Zardini, A. A., Clairotte, M., Astorga, C., Wolf, R., Slowik, J. G., Temime-Roussel, B., Marchand, N., Ježek, I., Drinovec, L., Močnik, G., Möhler, O., Richter, R., Barmet, P., Bianchi, F., Baltensperger, U., and Prévôt, A. S. H.: Secondary organic aerosol formation from gasoline vehicle emissions in a new mobile environmental reaction chamber, Atmos. Chem. Phys., 13, 9141-9158, https://doi.org/10.5194/acp13-9141-2013, 2013.

Platt, S. M., El Haddad, I., Pieber, S. M., Huang, R.-J. Zardini, A. A., Clairotte, M., Suarez-Bertoa, R., Barmet, P., Pfaffenberger, L., Wolf, R., Slowik, J. G., Fuller, S. J, Kalberer, M., Chirico, R., Dommen, J., Astorga, C., Zimmermann, R., Marchand, N., Hellebust, S., Temime-Roussel, B., Baltensperger, U., and Prévôt, A. S. H.: Two-stroke scooters are a dominant source of air pollution in many cities, Nat. Commun., https://doi.org/10.1038/ncomms4749, 2014.

Platt, S. M., El Haddad, I., Pieber, S. M., Zardini, A. A., SuarezBertoa, R., Clairotte, M., Daellenbach, K. R., Huang, R.-J., Slowik, J. G., Hellebust, S., Temime-Roussel, B., Marchand, N., de Gouw, J., Jimenez, J. L., Hayes, P. L., Robinson, A. L., Baltensperger, U., Astorga, C., and Prévôt, A. S. H.: Gasoline cars produce more carbonaceous particulate matter than modern filter-equipped diesel cars, Sci. Rep.-UK, 7, 1-9, 2017.

Ravindra, K., Sokhi, R., and Van Grieken, R.: Atmospheric polycyclic aromatic hydrocarbons: Source attribution, emission factors and regulation, Atmos. Environ., 42, 2895-2921, 2008.

R'Mili, B., Le Bihan, O. L. C., Dutouquet, C., Aguerre-Charriol, O., and Frejafon, E.: Particle sampling by TEM grid filtration, Aerosol Sci. Technol., 47, 767-775, 2013.

R'Mili, B., Boréave, A., Meme, A., Vernoux, P., Leblanc, M., Noël, L., Raux, S., and D'Anna, B.: Physico-chemical characterization of fine and ultrafine particles emitted during diesel particulate filter active regeneration of Euro5 diesel vehicles, Environ. Sci. Tech., 52, 3312-3319, 2018.

Rönkkö, T., Pirjola, L., Ntziachristos, L., Heikkilä, J., Karjalainen, P., Hillamo, R., and Keskinen, J.: Vehicle Engines Produce Ex- 
haust Nanoparticles Even When Not Fueled, Environ. Sci. Tech., 48, 2043-2050, 2014.

Ropkins, K., DeFries, T. H., Pope, F., Green, D. C., Kemper, J., Kishan, S., Fuller, G. W., Li, H., Sidebottom, J., Crilley, L. R., Kramer, L., Bloss, W. J., and Hager, J. S.: Evaluation of EDAR vehicle emissions remote sensing technology, Sci. Total Environ., 609, 1464-1474, 2017.

Saliba, G., Saleh, R., Zhao, Y., Presto, A. A., Lambe, A. T., Frodin, B., Sardar, S., Maldonado, H., Maddox, C., May, A. A., Drozd, G. T., Goldstein, A. H., Russell, L. M., Hagen, F., and Robinson, A. L.: Comparison of gasoline direct-injection (GDI) and port fuel injection (PFI) vehicle emissions: emission certification standards, cold-start, secondary organic aerosol formation potential, and potential climate impacts, Environ. Sci. Tech., 51, 6542-6552, 2017.

Samburova, V., Zielinska, B., and Khlystov, A.: Do 16 polycyclic aromatic hydrocarbons represent PAH air toxicity?, Toxics, 5, 17, https://doi.org/10.3390/toxics5030017, 2017.

Schuster, M. E., Hävecker, M., Arrigo, R., Blume, R., Knauer, M., Ivleva, N. P., Su, D. S., Niessner, R., and Schlögl, R.: Surface sensitive study to determine the reactivity of soot with the focus on the European emission standards IV and VI, J. Phys. Chem. A, 115, 2568-258, 2011.

Short, D. Z., Vu, D., Durbin, T. D., Karavalakis, G., and AsaAwuku, A.: Components of particle emissions from light-duty spark-ignition vehicles with varying aromatic content and octane rating in gasoline, Environ. Sci. Technol., 49, 10682-10691, 2015.

Slowik, J. G., Stainken, K., Davidovits, P., Williams, L. R., Jayne, J. T., Kolb, C. E., Worsnop, D. R., Rudich, Y., DeCarlo, P. F., and Jimenez, J. L.: Particle morphology and density characterization by combined mobility and aerodynamic diameter measurements. Part 2: application to combustion-generated soot aerosols as a function of fuel equivalence ratio, Aerosol Sci. Technol., 38, 1206-1222, 2004.

Smit, R., Kingston, P., Wainwright, D. H., and Tooker, R.: A tunnel study to validate motor vehicle emission prediction software in Australia, Atmos. Environ., 151, 188-199, 2017.

Song, J., Wang, J., and Boehman, A. L.: The role of fuel-borne catalyst in diesel particulate oxidation behavior, Combust. Flame, 146, 73-84, 2006.

Suarez-Bertoa, R., Zardini, A. A., and Astorga, C.: Ammonia exhaust emissions from spark ignition vehicles over the New European Driving Cycle, Atmos. Environ., 97, 43-53, 2014.

Timko, M. T., Yu, Z. H., Kroll, J., Jayne, J. T., Worsnop, D. R., Miake-Lye, R. C., Onasch, T. B., Liscinsky, D., Kirchstetter, T. W., Destaillats, H., Holder, A. L., Smith, J. D., and Wilson, K. R.: Sampling Artifacts from Conductive Silicone Tubing, Aerosol Sci. Technol., 43, 855-865, 2009.

Timko, M. T., Albo, S. E., Onasch, T. B., Fortner, E. C., Yu, Z., Miake-Lye, R. C., Canagaratna, M. R., Ng, N. L., and Worsnop, D. R.: Composition and sources of the organic particle emissions from aircraft engines, Aerosol Sci. Technol., 48, 61-73, 2014.

Tobias, H., Beving, D. E., and Ziemann, P. J.: Chemical analysis of diesel engine nanoparticles using a nano-DMA thermal desorption particle beam mass spectrometer, Environ. Sci. Technol., 35, 2233-2243, 2001.

Tutuianu, M., Bonnel, P., Ciuffo, B., Haniu, T., Ichikawa, N., Marotta, A., Pavlovic, J., and Steven, H.: Development of the
World-wide harmonized Light duty Test Cycle (WLTC) and a possible pathway for its introduction in the European legislation, Transp. Res. Part D, 40, 61-75, 2015.

Tyler, C. R., Zychowski, K. E., Sanchez, B. N., Rivero, V., Lucas, S., Herbert, G., Liu, J., Irshad, H., McDonald, J. D., Bleske, B. E., and Campen, M. J.: Surface areadependence of gas-particle interactions influences pulmonary and neuroinflammatory outcomes, Part Fibre Toxicol., 13, 64, https://doi.org/10.1186/s12989-016-0177-x, 2016.

Tzamkiozis, T., Ntziachristos, L., and Samaras Z.: Diesel passenger car PM emissions: From Euro 1 to Euro 4 with particle filter, Atmos. Environ., 44, 909-916, 2010.

Vouitsis, E., Ntziachristos, L., Pistikopoulos, P., Samaras, Z., Chrysikou, L., Samara, C., Papadimitriou, C., Samaras, P., and Sakellaropoulos, G.: An investigation on the physical, chemical and ecotoxicological characteristics of particulate matter emitted from light-duty vehicles, Environ. Pollut., 157, 2320-2327, 2009.

Wang, T., Jerrett, M., Sinsheimer, P., and Zhu, Y.: Estimating $\mathrm{PM}_{2.5}$-associated mortality increase in California due to the Volkswagen emission control defeat device, Atmos. Environ., 144, 168-174, 2016.

Weilenmann, M., Favez, J.-Y., and Alvarez, R.: Cold-start emissions of modern passenger cars at different low ambient temperatures and their evolution over vehicle legislation categories, Atmos. Environ., 43, 2419-2429, 2009.

Xu, Z., Li, X., Guan, C., and Huang, Z.: Effect of injection timing on exhaust particle size and nanostructure on a diesel engine at different loads, J. Aerosol Sci., 76, 28-38, 2014.

Yang, D., Fan, T., Zhou, H., Ding, J., and Zhang, D.: Biogenic Hierarchical $\mathrm{TiO}_{2} / \mathrm{SiO}_{2}$ Derived from Rice Husk and Enhanced Photocatalytic Properties for Dye Degradation, Plos One, 6, e24788, https://doi.org/10.1111/php.12873, 2011.

Yang, J., Roth, P., Durbin, T. D., Johnson, K. C., Cocker, D. R., AsaAwuku, A., Brezny, R., Geller, M., and Karavalakis, G.: Gasoline particulate filters as an effective tool to reduce particulate and polycyclic aromatic hydrocarbon emissions from gasoline direct injection (GDI) vehicles: A case study with two GDI ehicles, Environ. Sci. Technol., 52, 3275-3284, 2018.

Ye, P., Sun, C., Lapuerta, M., Aguledo, J., Vander Wal, R., Boehman, A. L., Toops, T. J., and Daw, S.: Impact of rail pressure and biodiesel fueling on the particulate morphology and soot nanostructures from a common-rail turbocharged direct injection diesel engine, Int. J. Engine Res., 17, 193-208, 2014.

Zhu, R., Hu, J., Bao, X., He, L., Lai, Y., Zu, L., Li, Y., and Su, S.: Tailpipe emissions from gasoline direct injection (GDI) and port fuel injection (PFI) vehicles at both low and high ambient temperatures, Environ. Pollut., 216, 223-234, 2016.

Zielinska, B., Sagebiel, J., McDonald, J. D., Whitney, K., and Lawson, D. R.: Emission rates and comparative chemical composition from selected in-use diesel and gasoline-fueled vehicles, JAPCA J. Air Waste Ma., 54, 1138-1150, 2004.

Zimmerman, N., Wang, J. M., Jeong, C. H., Wallace, J. S., and Evans, G. J.: Assessing the climate trade-offs of gasoline direct injection engines, Environ. Sci. Technol., 50, 8385-8392, 2016. 